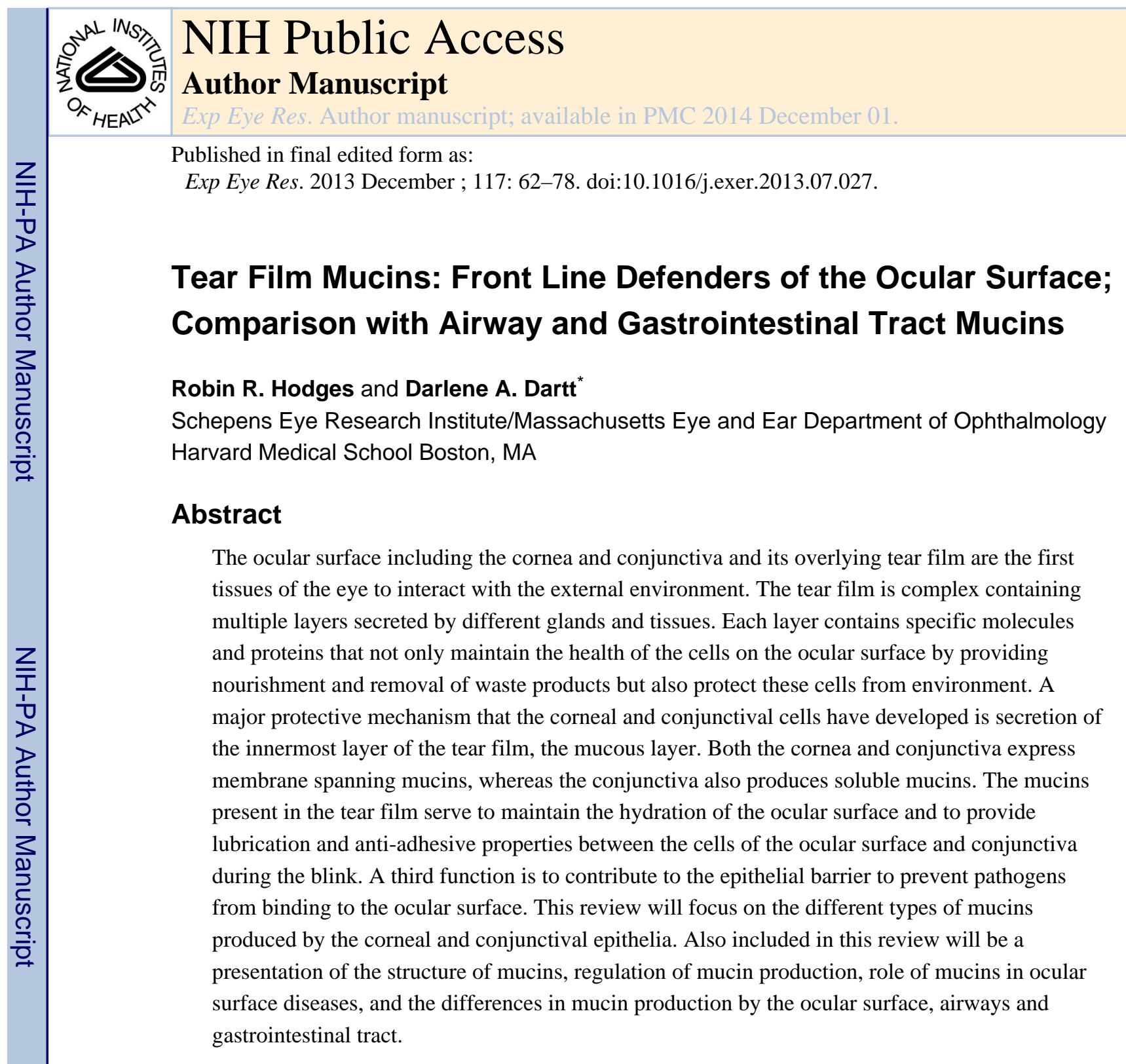

Keywords

Cornea; Conjunctiva; Mucin; Secretion; Proliferation; Tears

\title{
INTRODUCTION
}

The cornea, conjunctiva and the tear film comprise the ocular surface and are constantly exposed to the external environment (Figure 1). The ocular surface is protected from various environmental challenges by the tear film. The tear film is complex and contains multiple

\footnotetext{
(C) 2013 Elsevier Ltd. All rights reserved.

*Author to whom correspondence should be addressed: Darlene A. Dartt, 20 Staniford Street, Boston, MA 02114; Tel:617-912-0272; FAX: 617-912-0104; darlene_dartt@meei.harvard.edu.

Publisher's Disclaimer: This is a PDF file of an unedited manuscript that has been accepted for publication. As a service to our customers we are providing this early version of the manuscript. The manuscript will undergo copyediting, typesetting, and review of the resulting proof before it is published in its final citable form. Please note that during the production process errors may be discovered which could affect the content, and all legal disclaimers that apply to the journal pertain.
} 
layers secreted by different glands and tissues. The outermost portion of the tear film contains lipids secreted by the meibomian glands which are believed to block evaporation of the tears (Knop et al., 2011). The middle layer is the aqueous layer which consists of proteins, electrolytes, and water. The main contributor to this layer is the lacrimal gland though corneal and conjunctival epithelial cells also contribute (Dartt, 2004b). The innermost layer of the tear film is the mucous layer, which consists of secreted mucins, electrolytes, and water produced by the conjunctival goblet cells. In the cornea, membranespanning mucins are expressed in the apical cells to form the glycocalyx (Gipson and Argueso, 2003). In addition, both the cornea and conjunctiva, and to a lesser extent the lacrimal gland, express soluble mucins and ectodomain shed membrane-spanning mucins that have been detected in the tears (Carraway et al., 2002; Dartt, 2004a; Spurr-Michaud et al., 2007). This review will focus on synthesis, expression, and function of the membranespanning mucins of the glycocalyx as well as the soluble mucins found in the tears.

The cornea and conjunctiva differ structurally. The corneal epithelium that interfaces with the tear film on the apical side and the corneal stroma on the basal side is a multilayered, stratified epithelium (Figure 2A). Basal cells are a single layer of cuboidal cells that overlay the basement membrane. Several layers of stratified squamous cells form the apical aspect of the cornea (Figure 2A). Tight junctions between the epithelial cells insure a polarized epithelium with limited transcellular permeability. In addition, the epithelial cells have a very regular organization which contributes to transparency. The corneal epithelium is densely innervated especially with sensory, afferent nerves and the stroma is not vascularized.

The conjunctival epithelium surrounds the cornea and lines the eyelids. This epithelium abuts a loose stroma that contains elastic fibrils that allow the conjunctiva to stretch with eye movements and blinking. Shortening and relaxation of the conjunctiva also changes the number of layers of cells in its epithelium. The conjunctival epithelium consists of stratified squamous cells and goblet cells. Multiple layers of stratified squamous cells surround the goblet cells that occur singly or in clusters (Figure 2B). There are tight junctions between the conjunctival epithelial cells, but this epithelium is much more permeable that the cornea. The conjunctival epithelium is well innervated with sensory, parasympathetic, and sympathetic nerves. It is not as densely innervated with sensory afferent nerves as in the cornea. The conjunctival stroma is vascularized with leaky blood vessels.

The cornea and conjunctiva both have developed mechanisms to protect themselves from the external environment and prevent environmental challenges from penetrating their barriers, however the mechanisms differ between the two tissues. The cornea must maintain transparency so its responses are constrained and often different from other mucosal barrier tissues. The cornea must maintain its cellular and intercellular architecture and prevent the development of inflammation and its accompanying cellular responses of angiogenesis, edema, and cellular infiltration. One of the most important protective mechanisms of the corneal epithelium is its barrier function that is exceedingly tight preventing entrance of pathogens (except viruses), proteins, peptides, and other molecules. In the context of mucins, the cornea uses membrane-spanning mucins inserted into the apical membrane of the corneal cells to form a protective glycocalyx that interfaces with the tear film.

Exp Eye Res. Author manuscript; available in PMC 2014 December 01. 
The conjunctiva is substantially different from the cornea in its protective responses. The conjunctival epithelium is vascularized, has leaky tight junctions, and does not need to maintain transparency. It can swell with minimal consequences. While the cornea needs to dampen and manage its responses, the conjunctiva has developed a plethora of robust and overlapping responses. In the context of mucins, the conjunctival stratified squamous cells express membrane-spanning mucins while the goblet cells produce the large gel-forming mucin MUC5AC that is secreted into the tear film. It is unknown if MUC5AC forms a gel in the eye as it does in the gastrointestinal tract, but it is likely concentrated near the ocular surface as it is produced there. Goblet cells produce mucins in response to a myriad of different stimuli. The stratified squamous cells of the conjunctiva have an apical coat of membrane-spanning mucins similar to that of the cornea.

Thus the corneal and conjunctival epithelia have developed multiple, different mechanisms to respond to the constantly changing environmental conditions and challenges to protect the ocular surface and indeed the entire eye. The environmental challenges include: varying temperature (including burns), changing humidity, pathogenic infection (bacterial, viral, protozoal, and fungal), mechanical insults, and noxious as well as non-noxious chemicals. Production and release of mucins onto the ocular surface and into tears are one major protective mechanism that the cornea and conjunctiva have developed. This review will focus on the structure and regulation of production of different types of mucins produced by the corneal and conjunctival epithelia. Also included in this review will be a presentation of the role of mucins in ocular surface health and disease., Finally a brief discussion of the differences in mucin production by the ocular surface, airways and gastrointestinal tract will be included. The role of the eye-associated lymphoid tissue (EALT) in the protective mucosal immune system of the eye will not be discussed as this has been the subject of two recent reviews (Knop and Knop, 2010; Paulsen, 2008)

\section{OVERVIEW OF MUCINS}

Mucins consist of a protein backbone rich in serines and threonines, which are linked to a wide-variety of $O$-linked oligosaccharide side chains. These side chains make up more than $70 \%$ of the weight of the molecule. Up to 20 mucin genes MUC1-MUC2O have been identified in the human. These genes produce MUC1, MUC2, MUC3A, MUC3B, MUC4, MUC5AC, MUC5B, MUC6, MUC7, MUC8, MUC12, MUC13, MUC15, MUC16, MUC17, MUC19, MUC 20, and MUC21 (Kim and Ho, 2010; Niv and Boltin, 2012). Mucins are classified into two different types: membrane-spanning and secretory. Secretory mucins are further divided into non-gel-forming and large gel-forming. The gel-forming secretory mucins are MUC2, MUC5AC, MUC5B (also known as MUC9 or oviduct-specific glycoprotein (OVGP1)), MUC6 and MUC19. MUC7 and 8 are non-gel-forming secretory mucins. The remaining mucins are membrane-spanning. As indicated in Table 1 (Dharmani et al., 2009) mucins are located in the wet-surfaced epithelia of the body including the ocular surface, entire airway, and gastrointestinal tract in a tissue specific manner. Each cell type in each type of epithelium has its specific pattern of mucin expression. The amount of mucin produced is dependent upon regulation of mucin synthesis, mucin secretion, number of mucin producing cells (cellular proliferation), and mucin degradation.

Exp Eye Res. Author manuscript; available in PMC 2014 December 01. 


\section{MEMBRANE SPANNING MUCINS}

\section{Structure}

MUC1, $-3 \mathrm{~A} / \mathrm{B},-4,-12,-13,-15,-16,-17,-20$, and -21 comprise the family of membrane spanning mucins and are officially called cell surface associated mucins as determined by HUGO Gene Nomenclature Committee. These mucins have a short cytoplasmic domain, a hydrophobic membrane spanning domain and a large extracellular domain. The extracellular domain consists of tandem repeats that are rich in serine and threonine residues that are sites for $O$-glycosylation. Thus the extracellular domain of membrane spanning mucins is heavily glycosylated (Figure 3) (Hattrup and Gendler, 2008). The membranes spanning mucins differ to the variations in the extracellular and membrane spanning domains.

Membrane spanning mucins are composed of a two heterodimers of different sizes bound by a noncovalent bond (Hattrup and Gendler, 2008). The larger of the two heterodimers is completely extracellular and heavily glycosylated. The smaller heterodimer contains the transmembrane domain and the short cytoplasmic tail (CT). These two heterodimers are produced by the cleavage of a single membrane associated molecule at the extracellular SEA domain (Figure 3). MUC1 is synthesized as a single protein precursor polypeptide in the endoplasmic reticulum (ER) and is cleaved into two fragments that form a heterodimer. Nglycans are co-translationally added. Additional $N$ - and $O$-glycosylation occurs in Golgi apparatus as the protein moves to the plasma membrane (Theodoropoulos and Carraway, 2007). The modification of each mucin varies with cell type. Synthesis of MUC4 is similar to MUC1 though MUC4 exists in both a soluble and membrane-bound forms. Like MUCs 3A/B, 12, 13, and 17, MUC4 contains EGF-like domains, as well as a nidogen homology region, an adhesion-associated domain, and a von Willebrand factor type $\mathrm{D}$ sequence. Except for MUC4, von Willebrand factor type D sequence is only seen in gel-forming mucins (Hattrup and Gendler, 2008) (Figure 3). MUC16 is the largest membrane-bound mucin with the extracellular domain containing more than sixty tandem repeats (Bafna et al., 2010; Hattrup and Gendler, 2008). The cytoplasmic domain of MUC16 contains putative tyrosine and serine phosphorylation sites (Perez and Gipson, 2008) (Figure 3).

\section{Cellular Location}

MUC1, $-4,-15,-16$ and -20 are expressed on the ocular surface. MUC1, -4 and -16 have been the best studied and will be discussed below. It is not known which cell types of the ocular surface express MUC15 and -20. Interestingly, MUC20 appears to be one of the most highly expressed mucins in the human conjunctiva as determined by microarray analysis (Mantelli et al., 2009).

MUC1 has a molecular weight of 200-500 kDa (Brayman et al., 2004) and is the smallest of the three membrane spanning mucins found on the ocular surface. MUC4 has a molecular weight of approximately $900 \mathrm{kDA}$ while MUC16 is the largest with a molecular weight greater than 2.5 MDa (Hattrup and Gendler, 2008). MUC1, -4 and -16 are present in both the cornea and conjunctiva (Gipson and Argueso, 2003; Pflugfelder et al., 2000). MUC1 mRNA is detected in all cells of cornea and conjunctiva however the protein is only seen in

Exp Eye Res. Author manuscript; available in PMC 2014 December 01. 
apical cells of the cornea and apical and sub-apical stratified squamous cells of the conjunctiva. MUC4 mRNA is found across all areas of the conjunctiva, but in the cornea its presence decreases approaching the central cornea (Gipson, 2004). MUC16 mRNA was detected in the apical cells of the cornea and throughout all cell layers in the conjunctiva. MUC16 protein expression had the same distribution as its mRNA. Interestingly MUC1, -4 and -16 have also been identified in the lacrimal gland. In the lacrimal gland, MUC1 is present in the acinar cell membranes, while MUC4 and -16 were detected in acinar cells as both membrane bound and soluble forms. Soluble forms of all three membrane-spanning mucins have been detected in tears (Spurr-Michaud et al., 2007).

\section{Regulation of Production}

Mucin production is regulated at multiple levels. These levels include 1) transcription of genes, 2) translation of mRNA to protein, 3) post-translational modification, and 4) cellular differentiation. The promoter region of the MUC1 gene has been extensively studied in mammary cancer cells. These studies have demonstrated the promoter region has binding elements for the cytokines tumor necrosis factor a (TNFa), interleukin (IL) 6, interferon $\gamma$ (IFN $\gamma$ ), and transforming growth factor- $\beta$ (TGF- $\beta$ ) (Jonckheere and Van Seuningen, 2010). Estrogen, progesterone and glucocorticoid steroid response elements also bind to human MUC1 promoter (McGuckin et al., 1998; Treon et al., 1999). In addition androgens increase the expression of MUC1 (Mitchell et al., 2002). Similarly to MUC1, the promoter region of the MUC4 gene in pancreatic cancer cells also has binding regions for TNFa, IFN $\gamma$, and TGF $\beta$. In addition there is a binding site for retinoic acid (Jonckheere and Van Seuningen, 2010). There is little information on the regulation of MUC16 gene though phorbol esters and dexamethasone increased the amount of mRNA (Bae et al., 2012; Woo et al., 2010).

It has been shown that splice variants of MUC1 and 4 exist indicating that regulation of production also occurs at the mRNA level. Several different variants of MUC1 have been identified including variants with $\mathrm{N}$ - and $\mathrm{C}$ - terminal changes, soluble variants without the transmembrane and cytoplasmic domains, and variants lacking the region of variable tandem repeats (Hattrup and Gendler, 2008). In addition, at least twenty-four different transcripts have been identified for human MUC4 (Hattrup and Gendler, 2008).

An additional level of membrane-spanning mucin regulation occurs by post-translational modification. The most common post-translational modification is the glycosylation of the variable tandem repeat region. MUCs 1 and -4 also undergo proteolytic processing. MUC1 undergoes autoproteolytic cleavage as well as cleavage by matrix metalloproteinases

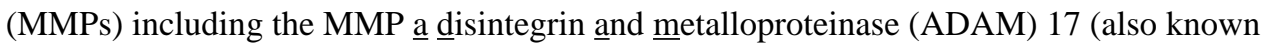
as TNFa converting enzyme abbreviated TACE) and membrane-type 1-matric metalloprotease (MT1-MMP) which allows MUC1 to be shed from the cell (Cullen, 2011) (Figure 3). On the ocular surface, neutrophil elastase and tumor necrosis factor a (TNFa) caused shedding on MUC16 while only TNFa caused shedding of MUC1 and MUC4 (Blalock et al., 2008). Xiong et al demonstrated that the posttranslational modification of MUC16 is regulated by Notch signaling (Xiong et al., 2011).

Membrane-spanning mucin expression is also dependent upon the differentiation stage of the cell type expressing the mucin. Therefore, mucin production is dependent on factors that 
cause differentiation (Theodoropoulos and Carraway, 2007). In the cornea, MUC1, -4 , and -16 are detected on the apical cells, which are the most differentiated cells of the cornea. MUC1, -4 , and -16 mRNA and protein has been shown to be upregulated by serum (Hori et al., 2004). Fibroblast growth factor 10 upregulated MUC1 and MUC4 mRNA (Ma et al., 2011). Hori et al demonstrated that retinoic acid increased the mRNA and protein expression of MUC16 mediated by secretory phospholipase A2 group IIA in a human conjunctival epithelial cell line (Hori et al., 2005). In addition, dexamethasone upregulated MUC16 expression in human corneal epithelial cells (Seo et al., 2007).

\section{Function of Membrane-spanning Mucins in the Tear Film}

It has not yet been established what, if any, unique and separate function each type of membrane-spanning mucin has on the ocular surface. However, in general, the membranespanning mucins play critical roles in the protection of the ocular surface. The $O$-glycans on membrane spanning mucins provide a rigid structure (so called bottle brush) allowing these mucins to extend 200-500 nm above (Argueso, 2013; Bramwell et al., 1986; Komatsu et al., 1997) the ocular surface. As the $O$-glycans are hydrophilic they bind water which helps to maintain their rigid structure (Argueso, 2013; Gipson, 2004). Thus it is thought that one function of these mucins is to maintain the hydration of the ocular surface. A second function of membrane-bound mucins is to provide lubrication and anti-adhesive properties between the cells of the ocular surface and conjunctiva during the blink (Argueso, 2013; Gipson, 2004). A third function is to contribute to the epithelial barrier. Argueso et al showed that MUC1 and -16 bind to galectin-3 on the apical surface of human cornea and conjunctiva (Argueso et al., 2009). Galectin-3 can cross-link glycan residues to generate lattices. When the cell surface was depleted of $O$-glycans, the amount of galectin-3 was reduced, and epithelial permeability as measured by Rose Bengal staining was increased.

$O$-glycans on membrane-spanning mucins are believed to restrict bacterial and viral access to the epithelium. In the gastrointestinal tract, mucins express complex oligosaccharides that act as decoy ligands for bacteria preventing the bacteria from binding to cells in the corneal or conjunctival epithelia (Guzman-Aranguez and Argueso, 2010). $O$-glycans are also known to prevent viruses from binding to cell surface. On the ocular surface, membrane-spanning mucins prevent binding of Staphylococcus aureus (S. aureus) and Streptococcus pneumonia to corneal and conjunctival epithelial cells, respectively (Argueso, 2013) as S.aureus was shown to bind to corneal epithelial cells which expressed truncated $O$-glycans (Ricciuto et al., 2008). This hypothesis is supported by an earlier study in which Kardon et al showed that MUC1 null mice are predisposed to developing eye inflammation compared to control mice (Kardon et al., 1999). However, other studies have not supported this hypothesis (Danjo et al., 2000).

Membrane-spanning mucins are also involved in cell signaling from the outside in (Figure 4). The cytoplasmic tail of MUC1 (MUC1CT) has been the best characterized. Extracellular signals such as bacteria and intracellular adhesion molecule 1 (ICAM-1) induce phosphorylation of MUC1CT that activates the the Wnt/ $\beta$-catenin, $\mathrm{p} 53$, and $\mathrm{NF} \kappa \mathrm{B}$ pathways. This activation results in translocation of MUC1CT to the nucleus where it could facilitate the transcriptional activation of genes involved in proliferation (Singh and

Exp Eye Res. Author manuscript; available in PMC 2014 December 01. 
Hollingsworth, 2006). Activation of the epidermal growth factor (EGF) receptor also phosphorylates MUC1CT to activate it. MUC1CT has numerous potential tyrosine phosphorylation sites. Activated MUC1CT can interact with the phospholipase $\mathrm{C} \gamma$ stimulated signaling pathways that result in production of the well-known signaling components intracellular $\left[\mathrm{Ca}^{2+}\right]$, protein kinase $\mathrm{C}$, and the $\mathrm{Grb} 2 / \mathrm{SOS}$ pathway that activates extracellular regulated kinase 1/2 (ERK1/2) (Figure 4). The EGF receptor stimulation has been linked to transformation of cells and tumor development (Raina et al., 2008). EGF receptor phosphorylation of MUC1CT interacts with an additional signaling pathway that protects against bacterial infection (Kato et al., 2012). This phosphorylation increases the association of MUC1 with Toll-like receptor 5 (TLR5) that is activated by gram negative bacteria such as Pseudomonas aeruginosa that can cause contact lens associated infections. This increase in association inhibits the recruitment of MyD88 to TLR5 and prevents proinflammatory signal transduction. MUC4 has extracellular EGF-like domains which bind to the EGF receptors ErbB2 and ErbB3. The MUC4-ErbB complexes have been hypothesized to prevent cancerous cells from undergoing apoptosis (Carraway et al., 2002). MUC4 and -16 both have one or more sites for tyrosine phosphorylation that could participate in outside in signaling. Several hypothetical mechanisms for these pathways are found in Singh and Hollingsworth (Singh and Hollingsworth, 2006)

Membrane spanning mucins have been found in tears (Pflugfelder et al., 2000; SpurrMichaud et al., 2007). It is known that MUC4 can be alternatively spliced into a variant that lacks a transmembrane region and is thus secreted into tears. MUC1, -4 , and -16 can also be present in tears due to ectodomain shedding. Ectodomain shedding of MUC1, but not -16 , was found to be dependent on the matrix metalloproteinase ADAM 17 (Figure 3). It is not known if the released mucins have a specific function in the tears which is different from their membrane-bound forms.

\section{Function of Membrane-spanning Mucins in Disease}

Abnormalities in the amount of mucins or their glycosylation profiles have been observed in a variety of cancers, inflammatory bowel disease, and gallstone disease (Chuang et al., 2012; Hattrup and Gendler, 2008; Sheng et al., 2012). Diseases of the ocular surface that involve altered mucin expression, distribution, or properties include dry eye syndrome, ocular cicatrizing diseases such as ocular cicatricial pemphigoid, Stevens Johnson syndrome, and vitamin A deficiency. In these diseases, goblet cells are lost and mucins are absent from the ocular surface. mRNAs of MUC1, and -4 , and -16 are also altered in patients with atopy, a severe form of allergic conjunctivitis. MUC16 mRNA was demonstrated to be significantly upregulated in patients with atopic kertoconjunctivitis (Dogru et al., 2008). A concomitant decrease in MUC5AC was also observed and the authors hypothesized that the increased MUC16 expression is an attempt to compensate for the decreased MUC5AC.

Alterations of the membrane-spanning mucins are also seen in patients with dry eye. The distribution of MUC16 is altered in patients with non-Sjogren's syndrome dry eye (Danjo et al., 2000) while mRNA levels of MUC1 as well as soluble MUC1 in tears of patients was increased with the autoimmune disease Sjogren's syndrome (Caffery et al., 2010). An increase in mRNA and protein of MUC1 and -16 were seen in post-menopausal women

Exp Eye Res. Author manuscript; available in PMC 2014 December 01. 
with non-Sjogren's syndrome dry eye compared to control patients (Gipson et al., 2011). MUC1 and -4 mRNA were also decreased in conjunctival epithelium of patients with dry eye (Corrales et al., 2011). Indeed it has been suggested that the amounts of MUC1 mRNA could be used as a biomarker for the diagnosis of dry eye as the expression levels of MUC1 showed a sensitivity of $83.3 \%$ and a specificity of $87.5 \%$ (Corrales et al., 2011).

One ocular sign of dry eye is rose bengal staining of the ocular surface. Blalock et al demonstrated that in a corneal cell line in which MUC16 has been suppressed, the amount of rose bengal staining increased compared to cells which expressed MUC16. Thus a decrease in MUC16 could be a component of dry eye disease. (Blalock et al., 2007).

Alterations of mucins in dry eye may be a result of inflammatory mediators that are produced in this disease. IL-6 has been shown to upregulate MUC1 protein while IFN- $\gamma$ and $\mathrm{TNFa}$ increase mRNA and protein of MUC1 in cultured human corneal epithelium (Albertsmeyer et al., 2010; Li et al., 2010). IL-1a, IL-1 $\beta$, and INF- $\gamma$ increased mRNA levels of MUC16 in a conjunctival epithelia cell line but downregulated it in a corneal epithelial cell line (Paulsen et al., 2008). In addition, the distribution of the enzymes responsible for $O$ glycosylation of mucins is altered in conjunctiva of dry eye patients (Mantelli et al., 2009). There are also indications that the splice variants of MUC1 may also play a role in dry eye (Imbert et al., 2006). However, use of MUC1 knockout mice have shown mixed results. One study showed that MUC1 knockout mice develop blepharitis and conjunctivitis while other studies reported no changes in tear film stability or bacterial adherence in these mice (Danjo et al., 2000; Kardon et al., 1999).

In complete androgen insensitivity syndrome, both the amount of message and protein for MUC1, and the gel-forming mucin MUC5AC, was decreased compared to control patients (Mantelli et al., 2007). As these patients have dry eye disease, this finding is further confirmation of a role for mucins in dry eye.

\section{Summary of Membrane Spanning Mucins}

Membrane spanning mucins play a key role in the health and maintenance of the cornea and conjunctiva, as well as other tissues. In addition to providing a protective barrier to prevent bacteria and viruses from binding, and providing lubrication, membrane spanning mucins also participate in cellular signaling. Much work remains to be done to decipher these roles of the membrane spanning mucins in health and disease.

\section{SMALL SECRETORY MUCINS}

\section{Structure}

MUC7 is a small soluble, monomeric mucin. This mucin is stored in secretory vesicles in cells and secreted upon stimulation. MUC7, also known as salivary mucin MG2, has a molecular weight of approximately $180 \mathrm{kDa}$ (Figure 5) (Gomes et al., 2011). Interestingly, MUC7 is expressed in human submandibular gland and trachea, but is not expressed in these tissues from rat, mouse, or hamster (Biesbrock et al., 1997). Several polymorphisms of MUC7 have been identified (Biesbrock et al., 1997) with one associated with a decreased risk of asthma (Kirkbride et al., 2001; Watson et al., 2009).

Exp Eye Res. Author manuscript; available in PMC 2014 December 01. 
MUC7 is a single polypeptide chain with five distinct domains (Gururaja et al., 1998).

Domain 1 is an N-terminal basic, histatin-like domain with a leucine zipper segment (Figure 5). Domain 2 is a moderately glycosylated domain. Domain 3 consists of six heavily glycosylated tandem repeats. Domain 4 is a heavily glycosylated MUC1- and MUC2-like domain. Finally, domain 5 forms the C-terminal portion as a leucin zipper segment. MUC7 also contains a high proline content that forms polyproline type structures. Crystal structural analysis suggests that the polyproline type II structure that is dispersed throughout the tandem repeats imparts a stiffening of the backbone to keep MUC7 in a semi-rigid rod shape like a "bottle-brush" model.

\section{Cellular Location}

MUC7 is the only small soluble mucin found in ocular tissue. MUC7 is expressed in the acinar cells of the lacrimal gland and in human conjunctiva (Corrales et al., 2003; Jumblatt et al., 2003; Paulsen et al., 2004). It is not known which cell type in the conjunctiva synthesizes and secretes MUC7. MUC7 has not been detected in tears (Jumblatt et al., 2003; Spurr-Michaud et al., 2007).

\section{Regulation of Production}

Similar to membrane-spanning mucins, the regulation of MUC7 is dependent upon its transcription of its gene, translation into protein, post-translational modification, and cellular differentiation. MUC7 has an additional level of regulation. As it is a secreted mucin, the amount of MUC7 present on the ocular surface is also dependent on stimuli of secretion. There is limited information on the regulation of production of MUC7, especially in ocular tissues. Cigarette smoke extract has been shown to upregulate MUC7 gene transcription and a combination of cigarette smoke extract and Pseudomonas aeruginosa increased MUC7 protein in respiratory tract (Fan and Bobek, 2010). In airway epithelial cells MUC7 gene expression was induced by lipopolysaccharide, IL-1 $\beta$, IL-4, IL-13, TNFa, and EGF (Li and Bobek, 2006).

MUC7 also undergoes post-translation modification as the mucin undergoes $O$-glycosylation of the serine and threonine residues in the five or six tandem repeats as do all mucins (Kirkbride et al., 2001). In the tandem repeat region there are several known polymorphisms of MUC7 that have been identified in the airway and in individuals with chronic periodontitis (Gomes et al., 2011; Rousseau et al., 2006). One polymorphism contains eight tandem repeats (Kirkbride et al., 2001).

There is little information on the effects of cell differentiation on MUC7 production, and none in the ocular surface. One study of human nasal epithelial cells demonstrated that upon removal of retinoic acid and raising the culture to an air-liquid interface allowing for differentiation of the cells, message for MUC7 increased (Yoon et al., 2000). In airway epithelial cells, one study showed that differentiation does not regulate MUC7 expression (Bernacki et al., 1999) while a second study demonstrated that inducing differentiation of airway epithelial cells by culturing the cells at the air-liquid interface stimulated the expression of MUC7 mRNA (Li and Bobek, 2006).

Exp Eye Res. Author manuscript; available in PMC 2014 December 01. 
In airway epithelial cells MUC7 protein secretion was induced by IL-1 $\beta$, IL-4, IL-13, TNFa, and EGF, the same stimuli as mRNA expression ( $\mathrm{Li}$ and Bobek, 2006). There is no information on stimuli of MUC7 secretion in ocular tissues.

\section{Function of Small Soluble Mucins in the Tear Film}

The function of MUC7 on the ocular surface is not well understood as MUC7 has been detected in the lacrimal gland and conjunctiva but not in tear samples. If MUC7 is secreted onto the ocular surface, it is likely that MUC7 is involved in preventing pathogen binding. Indeed, MUC7 has been shown to inhibit colonization of bacteria in oral cavity and trachea by masking their surface adhesins (Bobek et al., 1998). The D1, histatin-like domain of MUC7 has also been shown to have antifungal activity (Situ and Bobek, 2000). Similar to membrane spanning mucins, small soluble mucins are also likely to contribute to the hydration of the ocular surface and lubrication of the ocular surface during the blink.

\section{Function of Small Secretory Mucins in Disease}

There are no studies investigating the expression of MUC7 in any ocular disease. In other diseases such as chronic rhinosinusitis, there is an alteration in terminal sugars of MUC7 (Tan et al., 2010) while the MUC7 protein was increased in patients infected with Helicobacter pylori (H. pylori) (Silva et al., 2009). mRNA from MUC7 has been detected in the lymph nodes of bladder cancer patients and is under investigation as a potential indicator for metastasis and disease progression (Kinjo et al., 2004; Retz et al., 2004).

\section{Summary of Small Secretory Mucins}

Small secretory mucins are critical to the health of tissues such as the respiratory tract, and likely the ocular surface by preventing colonization of bacteria as well as contributing to hydration of the tissue. Much work on the role of MUC7 on the ocular surface, specific cells on the ocular surface that express MUC7, and what type of stimuli cause MUC7 secretion remains to be done.

\section{GEL-FORMING MUCINS}

\section{Structure}

MUC2, $-5 \mathrm{AC}, 5 \mathrm{~B}$, and -6 and -19 comprise the gel-forming mucins (Figure 6). These mucins are the largest glycoproteins known with molecular weights of mature proteins of approximately $40 \mathrm{mDa}$ (Gipson and Argueso, 2003). The protein cores of these mucins are encoded by the largest genes known. Each gel-forming mucin is encoded by separate genes. This mucin subtype has a large central tandem repeat region flanked by cysteine domains that are homologous to the D domains of von Willibrand factor (Gipson and Argueso, 2003). The cysteine rich domains form disulfide bonds to allow dimerization and multimerization which causes the gel-like mucus. For a more comprehensive review of gel-forming mucin structure see Perez-Vilar et al (Perez-Vilar et al., 2006). Gel-forming mucins are stored in secretory vesicles that fuse with the plasma membrane upon appropriate stimuli releasing mucins onto the mucosal surface (Dartt, 2004a; Evans et al., 2009; Perez-Vilar et al., 2006).

Exp Eye Res. Author manuscript; available in PMC 2014 December 01. 


\section{Cellular Location}

All gel-forming mucins have been detected in tissues of the ocular surface and related lacrimal gland. MUC2 and MUC5AC have also been detected in tears (Spurr-Michaud et al., 2007). Goblet cells of the conjunctiva are the main source of gel-forming mucins with MUC5AC being the most abundant mucin and the best studied. MUC2 message was also detected in human conjunctiva though the cell type which synthesizes this mucin is unknown (McKenzie et al., 2000). MUC19 was recently identified as being present in conjunctival epithelial and goblet cells and apical cells of the cornea (Yu et al., 2008). mRNA for MUC2, $-5 \mathrm{AC},-5 \mathrm{~B},-6$, and -19 has also been found in the lacrimal gland (Paulsen et al., 2004; Yu et al., 2008).

\section{Regulation of Production}

Regulation of Mucin Genes-The amount of MUC5AC depends on the transcription of the gene, processing of the mRNA, post translational modification of the protein, and differentiation of the cell type expressing the mucin. Inflammatory mediators, such as $\mathrm{TNFa}$ and prostaglandin E2 have been shown to increase mRNA expression of MUC5AC and -2, but not MUC5B in cultured airway epithelial cells (Rose and Voynow, 2006). IL-1 $\beta$ also increases MUC2 and -5AC gene expression in nasal epithelial cells through a signaling pathway that includes mitogen and stress-activated kinase 1 and cAMP response elementbinding protein (CREB) (Rose and Voynow, 2006). EGF family members also increase gene expression of MUC2 and -5AC. IL6/IL17 and IL8 upregulate MUC5AC and -5B, respectively. This finding suggests differential regulation of the two genes that synthesize these mucins (Rose and Voynow, 2006).

In the eye, little is known about the gene expression of gel-forming mucins. It is known that estrogen and progesterone do not regulate MUC4 and MUC5AC mRNA levels in the cornea and conjunctiva (Lange et al., 2003). MUC5AC gene expression was also shown to be downregulated in the absence of retinoic acid (Tei et al., 1999).

Select inflammatory mediators regulate mucin genes by increasing the stability of the mRNA. TNFa and IL-8 stabilize the mRNA of MUC5AC in human airway epithelial cells and the phorbol ester, 12-O-tetradecanoylphorbol-13-acetate, and forskolin that elevates cellular cAMP levels increase MUC2 levels post-transcriptionally via protein kinase $\mathrm{C}$ (PKC) or protein kinase A (PKA) pathways (Rose and Voynow, 2006).

Gel-forming mucins are heavily glycosylated post translationally hence their very large molecular weights (Hattrup and Gendler, 2008). MUC5AC is $O$-glycosylated in the Golgi apparatus prior to packaging in the secretory granules (Sheehan et al., 2004; Silverman et al., 2001). Mucins are $O$-glycosylated at their PTS domains that contain abundant serine, threonine, and proline amino acid residues (Johansson et al., 2011). This gives them their bottle brush-like extended and stiff conformation. $O$-glycolsylation is initiated by one of 20 different peptidyl-GalNAc-transferases that have specificity for peptide core sequences. The added GalNAc is then the substrate for further glycosylation by Gal- and GlcNActranferases. Cells from different tissues have their specific glycosyltransferases. In addition, the localization of the transferases within the Golgi apparatus is important. Transferases are

Exp Eye Res. Author manuscript; available in PMC 2014 December 01. 
localized according to the $\mathrm{pH}$ gradient over the Golgi stack. $O$-glycosylation is a dynamic process and can be altered in disease. These mucins also undergo sulfation, sialylation, and proteolysis (Perez-Vilar et al., 2006). Gel-forming mucins also form disulfide bonds with one another to generate multimers (Perez-Vilar et al., 2006). Hansson has demonstrated that in the stomach for MUC2 that the $\mathrm{C}$ termini of two molecules form disulfide bonds and the $\mathrm{N}$-termini link into trimers (Hansson, 2012). The large gel forming mucins are secreted as disulfide-bonded polymeric structures. The mechanisms by which they are formed and organized in cells and then released very rapidly are not well understood. Kesimer et al (Kesimer et al., 2010) found that MUC5B is assembled in a secretory granule organized around a number of nodes, each attached to four to eight subunits. This storage allows for efficient packaging of a number of large heavily glycosylated monomers while still permitting rapid unfolding and hydration. A rapid exchange of $\mathrm{Na}^{+}$for $\mathrm{Ca}^{2+}$ in the secretory granules provides the driving force for hydration.

Regulation of Goblet Cell Differentiation and Proliferation-There is little information on regulation of conjunctival goblet cell differentiation. In the eye, MUC5AC is secreted mostly by the goblet cells of the conjunctiva. In rodents, the goblet cells appear 7 days after birth about the same time MUC5AC message is first detected. Goblet cell numbers increase dramatically by eyelid opening at day 14 after birth (Rios et al., 2000; Tei et al., 1999). Wei et al suggest that goblet cells have different progenitor cells than corneal epithelial cells (Wei et al., 1995). Pellegrini et al demonstrated that conjunctival stem cells are distributed throughout the bulbar and fornical conjunctiva and that stratified squamous cells and goblet cells arise from a common bipotent stem cell (Pellegrini et al., 1999). Nerve growth factor (NGF) has been shown to induce differentiation (Lambiase et al., 2009). Kruppel-like transcription factors KLF4 and KLF5 appear to be critical to transcription of development of goblet cells as deletion of these genes completely abolished the presence of goblet cells in mouse conjunctiva (Gupta et al., 2011; Kenchegowda et al., 2011).

Furthermore, Notch binds to a promoter on KLF4 to induce MUC5AC synthesis and goblet cell differentiation (Zhang et al., 2013).

The amount of MUC5AC present on the ocular surface is also dependent on the number of goblet cells present in the conjunctiva. Conjunctival goblet cells have been shown to slowly traverse the cell cycle and proliferate in vivo. It is thought that this slow cycling under normal conditions may be due to the fact that the primary function of goblet cells is to secrete mucins. Since secretion can occur multiple times over the life span of the cell, goblet cells do not need to proliferate extensively. (Wei et al., 1995). The ability to culture human and rat goblet cells from conjunctival pieces paved the way for study the regulation of conjunctival goblet cell proliferation (Shatos et al., 2003; Shatos et al., 2001). Several members of the EGF family, namely EGF (which binds to EGF receptor, EGFR), TGFa (which binds to EGFR), and heparin binding EGF (which binds to EGFR and ErbB-4 a member of the EGFR family), but not heregulin (which binds to ErbB-3, another member of the EGFR family, and ErbB-4), stimulated goblet cell proliferation (Gu et al., 2008). EGF, TGFa, and HB-EGF activated several protein kinases including extracellular regulated kinase (ERK)1/2 (also known as p44/p42 mitogen-activated protein kinase (MAPK)), Janus kinase (JNK), and p38 mitogen-activated protein kinase (MAPK), but not AKT (a substrate

Exp Eye Res. Author manuscript; available in PMC 2014 December 01. 
phosphorylated by phosphoinositide-3 kinase (PI3K)). All members of EGF family of receptors were present on conjunctival goblet cells, including EGFR, ErbB-2, ErbB-3, and ErbB-4, however only the EGFR, ErbB-2, and ErbB-3 were active. None of the members of the NGF family caused goblet cells to proliferate even though their receptors were present on conjunctival goblet cells (Rios et al., 2007).

The signaling pathways activated by EGF were investigated in detail in human and rat goblet cells. EGF activates a single complex pathway to stimulate goblet cell proliferation. EGF binds to the EGF receptor and phosphorylates it at specific tyrosine residues (Figure 7) (Shatos et al., 2008). Each tyrosine residue is linked to distinct adapter proteins that activate explicit signaling pathways. In conjunctival goblet cells a single complex pathway is activated. First phospholipase $\mathrm{C} \gamma$ is induced to increase the intracellular $\left[\mathrm{Ca}^{2+}\right]$ and activate $\mathrm{PKC}$ isoforms. The $\mathrm{PKC}$ isoforms $\mathrm{PKCa}$ and $\mathrm{PKC} \varepsilon$ are responsible for inducing cell proliferation (Shatos et al., 2008; Shatos et al., 2009a; Shatos et al., 2009b). Active PKCa induces Src, a non-receptor tyrosine kinase, to stimulate phosphorylation of AKT by PI3K (unpublished data). Phosphorylated (active) AKT induces the phosphorylation of ERK1/2 (Shatos et al., 2008). A pathway of Sos, Ras, Raf, and MEK can activate ERK1/2, but it is not known if AKT interacts with one of these compounds or interacts with the pathway at the level of ERK1/2. Phosphorylated ERK1/2 translocates to the nucleus stimulating the goblet cells to progress through the cell cycle and divide (Shatos et al., 2008).

Regulation of Goblet Cell Secretion-The amount of MUC5AC on the ocular surface is also dependent upon the stimulation of its secretion. As goblet cells of the conjunctiva are at the interface of the environment and the ocular surface it would be advantageous for these cells to be able to respond quickly to stimuli from the external environment to produce a protective layer of mucus in the tear film. Indeed goblet cell secretion is neurally regulated. Conjunctival goblet cells are surrounded by parasympathetic and sympathetic nerves and receptors for parasympathetic and sympathetic nerves are located on the goblet cells (Dartt et al., 1995; Diebold et al., 2001; Li et al., 2013b; Rios et al., 2000; Rios et al., 1999). Parasympathetic neurotransmitters acetylcholine (carbachol was used) and vasoactive intestinal peptide (VIP) stimulate conjunctival goblet cell secretion in vivo, in pieces of conjunctiva, and in cultured cells (Dartt et al., 1996; Hodges et al., 2012; Rios et al., 1999).

In addition to cholinergic agonists and VIP, nucleotides also stimulate mucin secretion. ATP and UTP that activate the $\mathrm{P}_{2} \mathrm{Y}_{2}$ purinergic receptor subtype stimulate goblet cell mucin secretion (Fujihara et al., 2002; Jumblatt and Jumblatt, 1998; Murakami et al., 2003). As ATP can be released from nerves, ATP can function in neural mediation of secretion.

Two types of growth factors EGF and NGF/brain-derived growth factor (BDNF) stimulated goblet cell secretion (Hodges et al., 2012) (Jain et al., 2011; Rios et al., 2007). Stimulation of conjunctival goblet cell secretion by growth factors could be a slower, longer-term mechanism of response to external stimuli than that mediated by neurotransmitters. The secretory function of growth factors could also provide a separate mechanism for stimulating secretion, if neural stimulation is dysfunctional.

Exp Eye Res. Author manuscript; available in PMC 2014 December 01. 
The signaling pathways by which stimuli increase mucin secretion have been extensively studied. Most stimuli investigated to date use the common signaling components of an increase in intracellular $\left[\mathrm{Ca}^{2+}\right]$ and phosphorylation of ERK1/2 to cause mucin secretion, even though the receptors and other signaling components activated differ. Cholinergic agonists interact with muscarinic receptors (MAchR) to stimulate secretion (Figure 8A). In conjunctival pieces $\mathrm{M}_{2} \mathrm{AchR}$, and $\mathrm{M}_{3} \mathrm{AchR}$, but not $\mathrm{M}_{1} \mathrm{AchR}$ were located on goblet cells (Rios et al., 1999). Cholinergic agonist stimulation of secretion was blocked to the greatest extent by $M_{3} A c h R$ antagonists and to a lesser extent by $M_{1} A c h R$ and $M_{2} A c h R$ antagonists. In cultured cells all three muscarinic receptors $\left(\mathrm{M}_{1} \mathrm{AchR}, \mathrm{M}_{2} \mathrm{AchR}\right.$, and $\left.\mathrm{M}_{3} \mathrm{AchR}\right)$ are present on goblet cells, but cholinergic agonists predominantly used the $\mathrm{M}_{1} \mathrm{AchR}$ to increase intracellular $\left[\mathrm{Ca}^{2+}\right]$ with lesser effects of the other two receptors (Hodges et al., 2012). Cholinergic agonists activate phospholipase $\mathrm{C}$ to increase intracellular $\left[\mathrm{Ca}^{2+}\right]$ and activate PKC isoforms to cause secretion (Figure 8A) (Dartt et al., 2000; Hodges et al., 2012). The increase in intracellular $\left[\mathrm{Ca}^{2+}\right]$ and activation of PKC induce Src, PYK2, and ERK1/2 to transactivate the EGFR (Hodges et al., 2007; Horikawa et al., 2003; Kanno et al., 2003). In addition cholinergic agonists activate matrix metalloproteinases of the ADAM family that release EGF or an EGF family member that in turn activates the EGFR. Activation of the EGFR increases intracellular $\left[\mathrm{Ca}^{2+}\right]$ and activates ERK1/2 to cause secretion (Dartt, 2002; Hodges et al., 2012).

VIP activates a pathway that is similar to cholinergic agonists, but does differ in several ways. VIP uses its two receptors VPAC 1 and 2 to stimulate secretion ( $\mathrm{Li}$ et al., 2013b). Unlike cholinergic agonists VIP activates adenylyl cyclase to increase cellular levels of cAMP (Figure 8B). Like cholinergic agonists VIP increases the intracellular $\left[\mathrm{Ca}^{2+}\right]$ and activates ERK1/2 to stimulate secretion. The rise in cAMP increased the intracellular $\left[\mathrm{Ca}^{2+}\right]$ and stimulated secretion, but did not activate ERK1/2. Also unlike cholinergic agonists VIP did not transactivate the EGFR (Li et al., 2013b).

\section{Function of Gel-Forming Mucins in the Tear Film}

Like membrane-spanning and small soluble mucins, gel-forming mucins are important for hydration and lubrication of the ocular surface. Because gel-forming mucins can form very large structures which act as barriers, it is also likely they play a key role in prevention of pathogens and foreign objects from binding to or damaging the cells on the ocular surface. It has also been hypothesized that gel-forming mucins clear foreign bodies and pathogens from the ocular surface by trapping them in the mucus layer and with the help of the blink move them into the nasolacrimal duct (Gipson and Argueso, 2003).

Regulation of goblet cell secretion by nerves ensures that goblet cells can rapidly respond to external stimuli to secrete MUC5AC, other components of the secretory granules, electrolytes and water that together comprise mucus onto the ocular surface. We hypothesize that milder stimuli (wind, cold, particulate matter) would cause a limited secretion of mucus whereas more intense stimuli (trauma, chemicals, pathogenic bacteria) would induce a greater secretion of mucus. The released mucus can trap pathogens or protect the underlying epithelium from particles and chemicals to protect the epithelium. We also hypothesize that growth factors probably released from the epithelial cells or sensory nerves could increase

Exp Eye Res. Author manuscript; available in PMC 2014 December 01. 
MUC5AC synthesis and induce goblet cell proliferation to sustain MUC5AC in the mucous layer of tears over the long term. More research is needed to substantiate these hypotheses.

\section{Function of Gel-Forming Mucins in Disease}

The role of goblet cells and their production of MUC5AC and mucus in disease has not been well studied. There are several reasons for this. First, goblet cells are identified by their secretory product using alcian blue-periodic acid Schiff's reagent (AB-PAS) or antibody to MUC5AC. When goblet cells secrete, they release all their secretory granules and can no longer be identified. Thus this method of measurement does not account for the whole goblet cell population (Kessler et al., 1995). Second, goblet cells that are migrating or proliferating likely lose their content of secretory products in vitro and hence would not be identified (Eidet et al., 2012). Third, for in vivo studies the number of goblet cells per unit area differs over the conjunctiva, so care must be taken to take samples from the same location in each individual (Kessing, 1968). Fourth, interpretation of changes in number of filled goblet cells can be challenging. A decrease in the number of filled goblet cells could indicate increase in secretion (short term effect) or a decrease in proliferation or mucin synthesis (long term effect) depending on the time frame of analysis. An increase in the number of filled goblet cells could indicate a decrease in secretion (short term effect) or an increase in proliferation (long term effect). Finally animal models of disease pathogenesis are either not available or the role of goblet cells has not been fully explored. A targeted exploration of the role of both the goblet cell MUC5AC mucin and the membrane-bound mucins MUC1, MUC4, and MUC16 in human disease especially is warranted.

Early studies on the role of goblet cells in disease have suggested that both a decrease and an increase in the number of filled goblet cells is associated with disease (Lemp, 1992).

Diseases of mucous deficiency include Vitamin A deficiency, anesthetic cornea (neurotrophic keratitis), herpetic keratitis, familial disautonomia, alkali burns, radiation burns, Stephens-Johnson syndrome, cicatricial pemphigoid, and late dry eye syndromes. Diseases of mucous overproduction are giant papillary conjunctivitis, vernal conjunctivitis, atopy, seasonal allergic conjunctivitis, mucous fishing syndrome, and early dry eye. Thus mucous production is tightly regulated and both increases and decreases are associated with ocular surface disease, with diseases of deficiency being the most devastating. It should be pointed out that both types of mucin (secreted and membrane-bound) may contribute to pathology. Study of the role of the different types of mucin in ocular surface inflammatory disease is a critical need to understand this area.

Studies of dry eye disease suggest a decrease in MUC5AC and filled goblet cells in this disease as indicated by Lemp (Lemp, 1992). In a recent clinical study, the number of filled and empty goblet cells was studied by impression cytology in increasing severity of dry eye disease (Moore et al., 2011). In the more severe dry eye (still moderate dry eye) a decrease in total number of goblet cells and in empty goblet cells occurred. A decrease in the mRNA and amount of MUC5AC in tears has been observed in Sjogren's syndrome patients (Argueso et al., 2002). The amount of MUC19 message, as well as protein, is also decreased in these patients (Yu et al., 2008). Two studies have been performed to date involving MUC5AC deficient mice (Floyd et al., 2012; Wang et al., 2009). Interestingly, no obvious

Exp Eye Res. Author manuscript; available in PMC 2014 December 01. 
abnormalities of the ocular surface observed in either study. Wang et al demonstrated that there was a decrease in the amount of mRNA for MUC5AC and an increase in MUC4 mRNA in the MUC5AC null mice (Wang et al., 2009). This implies that a MUC4 plays a compensatory role in situations of decreased MUC5AC. In a different MUC5AC null mouse strain Floyd et al showed that the mRNA for MUC5B was significantly increased while MUC4 message was not (Floyd et al., 2012). Thus in this latter strain MUC5B was acting in a compensatory manner for MUC5AC. Evaluation of the ocular surface was also performed testing tear film breakup time (TBUT), fluorescein staining to determine the health of the corneal epithelial cells and measurement of the volume of tears. TBUT was significantly decreased while fluorescein staining was greatly increased in the knockout mice compared to the wild type control. The volume of tears was not different between the two strains of mice (Floyd et al., 2012). Unfortunately, MUC5AC knock out mouse models for the study of the role of goblet cells in ocular surface disease may not provide insight into the role of goblet cells in human ocular surface disease.

Lemp suggested that ocular allergy is a disease of increased mucous production (Lemp, 1992). Aragona found an increase in filled goblet cells in patients with vernal conjunctivitis compared to normal controls (Aragona et al., 1996). A similar increase in filled goblet cells was found in patients with atopic keratoconjunctivitis (Roat et al., 1993). These studies suggest that goblet cell mucin production is upregulated in ocular allergy. However other studies showed a decrease in filled goblet cells and MUC5AC synthesis. The number of goblet cells and MUC5AC mRNA levels were significantly downregulated in patients with atopic keratoconjunctivits (Dogru et al., 2008). As MUC16 was upregulated in these patients, Dogu et al hypothesized that MUC16 also compensates for the lack of MUC5AC (Dogru et al., 2008). MUC5AC message and protein were also decreased in one patient with complete androgen insensitivity (produces dry eye) compared to control patients. Interestingly in this patient the number of goblet cells present was not altered (Mantelli et al., 2007).

Mucus secretion is a common symptom of seasonal or perennial allergic conjunctivitis. Several studies have demonstrated that the number of filled goblet cells in the conjunctiva decreased during allergic conjunctivitis (Kunert et al., 2001; Merayo-Lloves et al., 1995; Toda et al., 1995). In addition, Kunert showed that repeated applications of allergens not only caused a decrease in the number of goblet cells but also in the amount of MUC5AC and MUC4 mRNA (Kunert et al., 2001). Twenty-four hours after the final challenge the number of goblet cells remained decreased while the amount of MUC5AC and -4 mRNA message was increased compared to control mice. The authors suggest that goblet cell differentiation and mucin secretion are part of the local defense to protect the ocular surface (Kunert et al., 2001). The depletion in goblet cell numbers is consistent with an increase in mucin secretion decreasing the number of filled goblet cells and depleting of cellular MUC5AC levels.

No study has investigated the entire picture of mucous production in vivo in ocular surface health and disease by measuring filled, empty, and total goblet cells; MUC5AC synthesis; and MUC5AC in tears as secreted by the goblet cells. This along with better characterized animal models of ocular allergy could establish the role of mucins in disease. Meanwhile use

Exp Eye Res. Author manuscript; available in PMC 2014 December 01. 
of cultured goblet cells was used to determine the effect of allergic and inflammatory mediators on MUC5AC secretion.

A direct role for increased conjunctival goblet cell mucin production in allergic conjunctivitis has been supported by studies on conjunctival goblet cells in culture. Inflammation is one of the underlying pathogenic mechanisms in allergic conjunctivitis and multiple types of inflammatory mediators are produced during disease progression. Lipid mediators generated by cytosolic phospholipase $\mathrm{A}_{2}$ breakdown of arachidonic acid directly stimulated conjunctival goblet cell MUC5AC secretion in both human and rat cells (Dartt et al., 2011). Prostaglandin $\mathrm{D}_{2}$ and the cysteinyl leukotrienes (LT) $\mathrm{LTC}_{4}, \mathrm{LTD}_{4}$, and $\mathrm{LTE}_{4}$ each stimulated mucin secretion. $\mathrm{LTD}_{4}$ and $\mathrm{LTE}_{4}$ were studied most extensively. $\mathrm{LTD}_{4}$ and $\mathrm{LTE}_{4}$ used the CysLT1 receptor to increase the intracellular $\left[\mathrm{Ca}^{2+}\right]$ and activate ERK1/2. A different type of allergic mediator histamine that is released from mast cells also caused goblet cell secretion. Interestingly all four histamine receptors $\mathrm{H}_{1}-\mathrm{H}_{4}$ were present on goblet cells and activation of each of these receptors caused MUC5AC secretion (Hayashi et al., 2012). In addition each of the four histamine receptors increased the intracellular $\left[\mathrm{Ca}^{2+}\right]$ and histamine itself activated ERK1/2. Activation of the $\mathrm{H}_{2}$ receptor activated adenylyl cyclase and elevated cellular cAMP levels to increase the intracellular $\left[\mathrm{Ca}^{2+}\right]$. All pro-inflammatory mediators tested activated the same basic signaling components as used by cholinergic agonists and VIP. Taken together these results suggest conjunctival goblet cell mucin secretion is a direct target of pro-inflammatory mediators associated with the allergic response. These results also imply that conjunctival goblet cells have developed multiple, overlapping mechanisms to cause goblet cell secretion and protect the ocular surface.

Normal production of MUC5AC at the ocular surface is important for the health of this surface, but excess mucin production, especially chronically, is not. Thus pro-resolution mediators are produced after the development of the inflammatory response to actively terminate inflammation (Serhan and Petasis, 2011). These pro-resolution mediators are produced from arachidonic acid and other omega-3-fatty acids and include lipoxins, resolvins (Rv), and protectins. The resolvins RvE1, RvD1, and aspirin-triggered (AT) RvD1 have been studied in the conjunctiva. RvE1 and RvD1 blocked leukotriene-stimulated goblet cell secretion (Dartt et al., 2011). RvD1 and AT-RvD1 prevented histamine stimulation of secretion. RvD1 interacts with its receptor GPR32 to activate the protein kinases PKC and $\beta$ adrenergic receptor kinase 1 ( $\beta$ ARK1 also known as GRK2) (Li et al., 2013a). Activation of these kinases phosphorylates the $\mathrm{H}_{1}$ receptor (the only histamine receptor tested to date) thereby desensitizing it and preventing it from increasing the intracellular $\left[\mathrm{Ca}^{2+}\right]$, activating ERK1/2, and stimulating secretion (Figure 9). Surprisingly, RvD1 and AT-RvD1 themselves stimulate a small amount of mucin secretion. Thus the D-series resolvins block the overstimulation of mucin secretion by allergic mediators, allowing the goblet cells to return to normal, but at the same time these resolvins produce a little mucus to protect the ocular surface.

Summary of Gel-forming Mucin Regulation-Goblet cell mucin secretion must be tightly regulated to produce an optimal amount of mucus to overspread the ocular surface. In diseases of mucin deficiency such as dry eye, mucus depletion that could occur by: 1 . depletion of goblet cell secretory product perhaps from increased secretion without mucin 
re-synthesis and 2. goblet cell loss perhaps from a decrease in goblet cell proliferation and an increase in goblet cell death. In dry eye disease the inflammatory cytokines produced in tears and the upregulation of matrix metalloproteinases and inflammatory cytokines IL-1 and TNFa in the conjunctiva have been shown to play a role in the depletion of goblet cells and their mucin (Pflugfelder et al., 1999; Solomon et al., 2001; Tishler et al., 1998) (see chapter in this special issue).

In diseases of overproduction such as allergic conjunctivitis there is an overproduction in the amount of mucus. This could result from: 1 . an increase in the number of goblet cells caused by an increase in proliferation and a decrease in goblet cell death and 2. an increase in the amount of mucin produced and secreted caused by an increase mucin secretion with a concomitant increase in mucin synthesis. Evidence supports an increase in mucin secretion produced by the inflammatory mediators present in allergy for example and an increase in MUC5AC synthesis (Dartt et al., 2011; Kunert et al., 2001; Li et al., 2013a).

\section{Summary of Secretory Mucins}

Continued study of mouse models of ocular surface disease, human clinical studies using tear collection and impression cytology to sample the conjunctiva, and use of cultured conjunctival goblet and stratified squamous cells is important to increase understanding of the role of gel-forming mucins in diseases of the ocular surface.

\section{COMPARISON OF MUCIN DISTRIBUTION AND DISEASE RELATEDNESS IN OCULAR SURFACE, GASTROINTESTINAL TRACT, AND RESPIRATORY TRACT}

Mucins are present in all wet-surface mucosal epithelia including most simple secretory epithelia. In addition MUC1 is found on some hematopoetic cells (Hattrup and Gendler, 2008). However, mucins are best studied in the intestine/colon and airways. The types of mucins present, regulation of production, and role in health and disease differs between the ocular surface, gastrointestinal tract, and respiratory tract (Table 1). Whereas the conjunctival epithelium is stratified squamous and consists predominantly of two cell types the stratified squamous and goblet cells, the airway and intestinal epithelia are more complicated. The airway epithelium is columnar pseudostratified and contains ciliated, secretory, columnar and basal epithelial cells. Clara cells and goblet cells are secretory cells. A small population of goblet cells is present in the healthy epithelium. Mucous glands secrete the gel-forming mucins in the healthy epithelium. The intestinal and colonic epithelia are columnar epithelia that are organized into villi. Cells are produced in the crypts and then differentiate as they move to the tips of the villi. Cell types include absorptive enterocytes, enteroendocrine, Paneth, and goblet cells. Goblet cells change their responsiveness as they migrate up the villus.

The apical cell layer of conjunctival, airway, intestinal, and colonic epithelia each express a repertoire of membrane-spanning mucins (Table 1). In the conjunctiva and airways MUC 1, 4, and 16 have been detected (Gipson and Argueso, 2003; Hattrup and Gendler, 2008). In the intestine, MUC 1, 3, 4, 13, and 17 are present (Kim and Ho, 2010). In all these tissues a

Exp Eye Res. Author manuscript; available in PMC 2014 December 01. 
major function of the membrane-spanning mucins is to prevent bacteria from reaching the epithelial cell apical membranes and penetrating these cells (Gipson and Argueso, 2003; Hattrup and Gendler, 2008; Kim and Ho, 2010). The membrane-spanning mucins form a mesh that the bacteria cannot penetrate.

In the airways and intestine the large gel-forming mucins are the predominant mucin type present. As the cornea does not contain gel-forming mucins, both mucin types are more equal in the ocular surface than in the intestines or airways. The gel-forming mucin in the conjunctiva is MUC5AC and is found in the goblet cells (Table 1) (Inatomi et al., 1997). In the airways MUC5AC is present in the goblet cells and MUC5B in the mucous glands (Hattrup and Gendler, 2008). In the intestine MUC2 is present in and produced by the goblet cells (Evans and Koo, 2009). Regulation of gel-forming mucin production differs between the three tissues. The major regulation of MUC5AC production in the conjunctiva is by regulation of secretion (Dartt, 2002). This regulation is predominantly neural. In the airways, mucin secretion by the mucous glands is regulated by secretion. In contrast to regulation of mucous gland, goblet cell mucin secretion is controlled by differentiation of goblet cells from Clara cells that occurs in disease and by control of mucin synthesis. For mucous gland secretion the regulation is mostly by neural stimulation. Goblet cell regulation is predominantly through the control of mucin synthesis by inflammatory cytokines, bacterial products, growth factors, and environmental chemicals (Thai et al., 2008) although the purinergic agonists ATP and UTP and platelet activating factor (PAF) can also stimulate secretion (Davis and Dickey, 2008). In the intestine, goblet cell mucin production is regulated by secretion and by differentiation/migration of goblet cells. Secretion by goblet cells in the crypts is stimulated by cholinergic agonists and histamine (Neutra et al., 1982; Neutra et al., 1984). This stimulation is lost when cells are at the villi tips. In the colon VIP and neurotensin stimulate goblet cell secretion (Bou-Hanna et al., 1994).

The mucous layer produced by the gel-forming mucins differs between the ocular surface, airways, and intestine/colon, although the glycocalyx containing membrane associated mucins are more similar (Table 1). On the ocular surface there is a relatively thin mucous layer about $1 \mu \mathrm{m}$. It is unlikely that this layer is a true gel-forming layer as in the other two tissues. MUC5AC molecules may be degraded by proteolysis while on the surface and may also form a gradient in the aqueous layer, but this remains speculative. The mucous layer of the tear film is removed by the blink into the nasolacrimal duct and into the nose. The glycocalyx layer consisting of membrane associated mucins interfaces between the surface of the apical epithelial cells and the mucous layer.

In the airway the mucous layer is a gel layer of 7-70 $\mu \mathrm{m}$ thickness (Hattrup and Gendler, 2008). The mucous layer is in fact two layers, a pericilliary layer (PCL) that is adjacent to the epithelium and the upper mucous transporting layer. The PCL contains the cilia that beat to move the mucus back up the trachea where is it removed by the cough. The PCL was thought to be a watery layer that would allow the cilia to beat. Kesimer et al recently found that the membrane associated mucins MUC1, 4, and 16 project like bottle brushes from the epithelium in a highly dense gel-like mesh (Kesimer et al., 2010). This mesh restricts the entry of viruses and bacteria, but does not impart a viscous drag on the cilia. In fact this layer confers a lubricating property that facilitate ciliary beating. This beating then

Exp Eye Res. Author manuscript; available in PMC 2014 December 01. 
transports the large-gel forming mucins MUC5AC and MUC5B in the upper mucous layer up the trachea.

The mucous layer of the intestine and colon is the most complex. In the intestine there is one layer, but in the colon there are two. MUC2, the gel forming mucus of the intestine and colon is secreted as a net-like structure that forms flat sheets. The net-like structure derives from the disulfide bonded di- and trimmers of MUC2 as well as by non-reducible bonds (Johansson et al., 2011). In addition there is a large protein immunoglobulin $\mathrm{Fc} \gamma$ binding domain (FCGBP) that is covalently attached to MUC2. Thus MUC2 highly structured and well stabilized. In the intestine the mucous layer is easy to aspirate and permeable to bacteria. In the two-layered system of the colon, the inner layer remains attached to the epithelium and has special physical properties. The inner layer is 50-100 $\mu \mathrm{m}$ thick. The outer layer forms from the inner layer by a protease-dependent four-fold expansion, This layer is loose and can be aspirated. It can be $480 \mu \mathrm{m}$ thick or more (Kim and Ho, 2010). Bacteria are found only in the outer layer and are absent from the inner layer. In fact the outer mucous layer is the habitat for the commensal bacteria of the colon. This separates the bacteria from the immune system. As in the ocular surface and airways, there is also a dense glycocalyx of membrane associated mucins that protects the enterocytes.

In health all three epithelial have protective functions that are uniquely adapted to their individual environments. The intestinal and especially the colonic mucous layer has an unusual challenge in that the lumen normally contains a large microbiome (Kim and Ho, 2010). Intestinal and colonic epithelial cells must respond very differently to the commensal bacteria than to pathogenic bacteria. Similar response mechanisms must be present in the airway and ocular surface epithelia, but the bacterial load is substantially smaller in these latter tissues.

Select diseases affect each of the three mucous producing epithelia (Table 1). In the ocular surface there are two major disease types dry eye disease and allergic conjunctivitis. Both membrane-spanning and gel-forming mucins play a role in pathogenesis. As dry eye is associated with a decrease in mucous and allergic conjunctivitis with an increase in mucous, mucous production by this tissue most be tightly regulated. Diseases of mucous deficiency are the most devastating. In the airway and intestine, disease is predominantly associated with an increase in gel-forming mucous secretion that is particularly destructive and pathogenic in the airways. The diseases affecting the lung are asthma, cystic fibrosis (CF), and chronic obstructive pulmonary disease (COPD). An increase in the amount and character of the gel-forming mucin along with an increase in the number and size of goblet cells are the primary mucous problems in these diseases. In the intestine the major diseases are infection, $\mathrm{CF}$, and inflammatory bowel disease (IBD). In these diseases there is an increase in gel-forming mucous production in an attempt to remove the bacteria or other inflammatory products or cells present.

\section{Conclusion}

Membrane-spanning and gel-forming mucins produced by the corneal and conjunctival epithelial cells are critical to the health of the ocular surface and protection of this tissue from the external environment. Dysregulation of mucin production is an important 
component of ocular surface disease most of which are inflammatory. However, additional research is necessary to determine the roles of the individual mucins in disease, the mechanisms responsible for the synthesis of each of the mucins, and the change in the components of mucin production in disease. Development of new animal models of ocular surface disease as well as thorough study of mucin production in patients with ocular surface disease is needed to better describe the role of mucins in ocular surface disease.

\section{References}

Albertsmeyer AC, Kakkassery V, Spurr-Michaud S, Beeks O, Gipson IK. Effect of pro-inflammatory mediators on membrane-associated mucins expressed by human ocular surface epithelial cells. Exp Eye Res. 2010; 90:444-451. [PubMed: 20036239]

Aragona P, Romeo GF, Puzzolo D, Micali A, Ferreri G. Impression cytology of the conjunctival epithelium in patients with vernal conjunctivitis. Eye (Lond). 1996; 10(Pt 1):82-85. [PubMed: 8763308]

Argueso P. Glycobiology of the ocular surface: mucins and lectins. Jpn J Ophthalmol. 2013; 57:150155. [PubMed: 23325272]

Argueso P, Balaram M, Spurr-Michaud S, Keutmann HT, Dana MR, Gipson IK. Decreased levels of the goblet cell mucin MUC5AC in tears of patients with Sjogren syndrome. Invest Ophthalmol Vis Sci. 2002; 43:1004-1011. [PubMed: 11923240]

Argueso P, Guzman-Aranguez A, Mantelli F, Cao Z, Ricciuto J, Panjwani N. Association of cell surface mucins with galectin-3 contributes to the ocular surface epithelial barrier. The Journal of biological chemistry. 2009; 284:23037-23045. [PubMed: 19556244]

Bae M, Woo M, Kusuma IW, Arung ET, Yang CH, Kim YU. Inhibitory effects of isoflavonoids on rat prostate testosterone 5alpha-reductase. J Acupunct Meridian Stud. 2012; 5:319-322. [PubMed: 23265084]

Bafna S, Kaur S, Batra SK. Membrane-bound mucins: the mechanistic basis for alterations in the growth and survival of cancer cells. Oncogene. 2010; 29:2893-2904. [PubMed: 20348949]

Bernacki SH, Nelson AL, Abdullah L, Sheehan JK, Harris A, Davis CW, Randell SH. Mucin gene expression during differentiation of human airway epithelia in vitro. Muc4 and muc5b are strongly induced. Am J Respir Cell Mol Biol. 1999; 20:595-604. [PubMed: 10100990]

Biesbrock AR, Bobek LA, Levine MJ. MUC7 gene expression and genetic polymorphism. Glycoconj J. 1997; 14:415-422. [PubMed: 9249138]

Blalock TD, Spurr-Michaud SJ, Tisdale AS, Gipson IK. Release of membrane-associated mucins from ocular surface epithelia. Invest Ophthalmol Vis Sci. 2008; 49:1864-1871. [PubMed: 18436821]

Blalock TD, Spurr-Michaud SJ, Tisdale AS, Heimer SR, Gilmore MS, Ramesh V, Gipson IK. Functions of MUC16 in corneal epithelial cells. Invest Ophthalmol Vis Sci. 2007; 48:4509-4518. [PubMed: 17898272]

Bobek LA, Li H, Rojstaczer N, Jones C, Gross KW, Levine MJ. Tissue-specific expression of human salivary mucin gene, MUC7, in transgenic mice. Transgenic Res. 1998; 7:195-204. [PubMed: 10461391]

Bou-Hanna C, Berthon B, Combettes L, Claret M, Laboisse CL. Role of calcium in carbachol- and neurotensin-induced mucin exocytosis in a human colonic goblet cell line and cross-talk with the cyclic AMP pathway. Biochem J. 1994; 299(Pt 2):579-585. [PubMed: 8172620]

Bramwell ME, Wiseman G, Shotton DM. Electron-microscopic studies of the CA antigen, epitectin. Journal of cell science. 1986; 86:249-261. [PubMed: 2443520]

Brayman M, Thathiah A, Carson DD. MUC1: a multifunctional cell surface component of reproductive tissue epithelia. Reprod Biol Endocrinol. 2004; 2:4. [PubMed: 14711375]

Caffery B, Heynen ML, Joyce E, Jones L, Ritter R 3rd, Senchyna M. MUC1 expression in Sjogren's syndrome, KCS, and control subjects. Mol Vis. 2010; 16:1720-1727. [PubMed: 20806091]

Carraway KL, Perez A, Idris N, Jepson S, Arango M, Komatsu M, Haq B, Price-Schiavi SA, Zhang J, Carraway CA. Muc4/sialomucin complex, the intramembrane ErbB2 ligand, in cancer and

Exp Eye Res. Author manuscript; available in PMC 2014 December 01. 
epithelia: to protect and to survive. Prog Nucleic Acid Res Mol Biol. 2002; 71:149-185. [PubMed: 12102554]

Chuang SC, Hsi E, Lee KT. Mucin genes in gallstone disease. Clin Chim Acta. 2012; 413:1466-1471. [PubMed: 22705400]

Corrales RM, Calonge M, Herreras JM, Saez V, Chaves FJ. Human epithelium from conjunctival impression cytology expresses MUC7 mucin gene. Cornea. 2003; 22:665-671. [PubMed: 14508262]

Corrales RM, Narayanan S, Fernandez I, Mayo A, Galarreta DJ, Fuentes-Paez G, Chaves FJ, Herreras JM, Calonge M. Ocular mucin gene expression levels as biomarkers for the diagnosis of dry eye syndrome. Invest Ophthalmol Vis Sci. 2011; 52:8363-8369. [PubMed: 21931132]

Cullen PJ. Post-translational regulation of signaling mucins. Curr Opin Struct Biol. 2011; 21:590-596. [PubMed: 21889329]

Danjo Y, Hazlett LD, Gipson IK. C57BL/6 mice lacking Muc1 show no ocular surface phenotype. Invest Ophthalmol Vis Sci. 2000; 41:4080-4084. [PubMed: 11095599]

Dartt DA. Regulation of mucin and fluid secretion by conjunctival epithelial cells. Prog Retin Eye Res. 2002; 21:555-576. [PubMed: 12433377]

Dartt DA. Control of mucin production by ocular surface epithelial cells. Exp Eye Res. 2004a; 78:173185. [PubMed: 14729350]

Dartt DA. Interaction of EGF family growth factors and neurotransmitters in regulating lacrimal gland secretion. Exp Eye Res. 2004b; 78:337-345. [PubMed: 15106911]

Dartt DA, Hodges RR, Li D, Shatos MA, Lashkari K, Serhan CN. Conjunctival goblet cell secretion stimulated by leukotrienes is reduced by resolvins D1 and E1 to promote resolution of inflammation. Journal of immunology. 2011; 186:4455-4466.

Dartt DA, Kessler TL, Chung EH, Zieske JD. Vasoactive intestinal peptide-stimulated glycoconjugate secretion from conjunctival goblet cells. Exp Eye Res. 1996; 63:27-34. [PubMed: 8983961]

Dartt DA, McCarthy DM, Mercer HJ, Kessler TL, Chung EH, Zieske JD. Localization of nerves adjacent to goblet cells in rat conjunctiva. Curr Eye Res. 1995; 14:993-1000. [PubMed: 8585938]

Dartt DA, Rios JD, Kanno H, Rawe IM, Zieske JD, Ralda N, Hodges RR, Zoukhri D. Regulation of conjunctival goblet cell secretion by $\mathrm{Ca}(2+)$ and protein kinase C. Exp Eye Res. 2000; 71:619-628. [PubMed: 11095914]

Davis CW, Dickey BF. Regulated airway goblet cell mucin secretion. Annu Rev Physiol. 2008; 70:487-512. [PubMed: 17988208]

Dharmani P, Srivastava V, Kissoon-Singh V, Chadee K. Role of intestinal mucins in innate host defense mechanisms against pathogens. J Innate Immun. 2009; 1:123-135. [PubMed: 20375571]

Diebold Y, Rios JD, Hodges RR, Rawe I, Dartt DA. Presence of nerves and their receptors in mouse and human conjunctival goblet cells. Invest Ophthalmol Vis Sci. 2001; 42:2270-2282. [PubMed: 11527940]

Dogru M, Matsumoto Y, Okada N, Igarashi A, Fukagawa K, Shimazaki J, Tsubota K, Fujishima H. Alterations of the ocular surface epithelial MUC16 and goblet cell MUC5AC in patients with atopic keratoconjunctivitis. Allergy. 2008; 63:1324-1334. [PubMed: 18782111]

Eidet JR, Fostad IG, Shatos MA, Utheim TP, Utheim OA, Raeder S, Dartt DA. Effect of biopsy location and size on proliferative capacity of ex vivo expanded conjunctival tissue. Invest Ophthalmol Vis Sci. 2012; 53:2897-2903. [PubMed: 22491407]

Evans CM, Kim K, Tuvim MJ, Dickey BF. Mucus hypersecretion in asthma: causes and effects. Curr Opin Pulm Med. 2009; 15:4-11. [PubMed: 19077699]

Evans CM, Koo JS. Airway mucus: the good, the bad, the sticky. Pharmacol Ther. 2009; 121:332-348. [PubMed: 19059283]

Fan H, Bobek LA. Regulation of Human MUC7 Mucin Gene Expression by Cigarette Smoke Extract or Cigarette Smoke and Pseudomonas aeruginosa Lipopolysaccharide in Human Airway Epithelial Cells and in MUC7 Transgenic Mice. Open Respir Med J. 2010; 4:63-70. [PubMed: 20802811]

Floyd AM, Zhou X, Evans C, Rompala OJ, Zhu L, Wang M, Chen Y. Mucin deficiency causes functional and structural changes of the ocular surface. PLoS One. 2012; 7:e50704. [PubMed: 23272068]

Exp Eye Res. Author manuscript; available in PMC 2014 December 01. 
Fujihara T, Murakami T, Nagano T, Nakamura M, Nakata K. INS365 suppresses loss of corneal epithelial integrity by secretion of mucin-like glycoprotein in a rabbit short-term dry eye model. $\mathbf{J}$ Ocul Pharmacol Ther. 2002; 18:363-370. [PubMed: 12222766]

Gipson IK. Distribution of mucins at the ocular surface. Exp Eye Res. 2004; 78:379-388. [PubMed: 15106916]

Gipson IK, Argueso P. Role of mucins in the function of the corneal and conjunctival epithelia. Int Rev Cytol. 2003; 231:1-49. [PubMed: 14713002]

Gipson IK, Spurr-Michaud SJ, Senchyna M, Ritter R 3rd, Schaumberg D. Comparison of mucin levels at the ocular surface of postmenopausal women with and without a history of dry eye. Cornea. 2011; 30:1346-1352. [PubMed: 22089171]

Gomes GP, Assis MA, Fonseca JS, de Souza PE, Zenobio EG, Oliveira DD, Soares RV. Genetic polymorphism of MUC7 in individuals with aggressive or chronic periodontitis. J Oral Sci. 2011; 53:445-449. [PubMed: 22167029]

Gu J, Chen L, Shatos MA, Rios JD, Gulati A, Hodges RR, Dartt DA. Presence of EGF growth factor ligands and their effects on cultured rat conjunctival goblet cell proliferation. Exp Eye Res. 2008; 86:322-334. [PubMed: 18155194]

Gupta D, Harvey SA, Kaminski N, Swamynathan SK. Mouse conjunctival forniceal gene expression during postnatal development and its regulation by Kruppel-like factor 4. Invest Ophthalmol Vis Sci. 2011; 52:4951-4962. [PubMed: 21398290]

Gururaja TL, Ramasubbu N, Venugopalan P, Reddy MS, Ramalingam K, Levine MJ. Structural features of the human salivary mucin, MUC7. Glycoconj J. 1998; 15:457-467. [PubMed: 9881747]

Guzman-Aranguez A, Argueso P. Structure and biological roles of mucin-type O-glycans at the ocular surface. Ocul Surf. 2010; 8:8-17. [PubMed: 20105403]

Hansson GC. Role of mucus layers in gut infection and inflammation. Current opinion in microbiology. 2012; 15:57-62. [PubMed: 22177113]

Hattrup CL, Gendler SJ. Structure and function of the cell surface (tethered) mucins. Annu Rev Physiol. 2008; 70:431-457. [PubMed: 17850209]

Hayashi D, Li D, Hayashi C, Shatos M, Hodges RR, Dartt DA. Role of histamine and its receptor subtypes in stimulation of conjunctival goblet cell secretion. Invest Ophthalmol Vis Sci. 2012; 53:2993-3003. [PubMed: 22467574]

Hodges RR, Bair JA, Carozza RB, Li D, Shatos MA, Dartt DA. Signaling pathways used by EGF to stimulate conjunctival goblet cell secretion. Exp Eye Res. 2012; 103:99-113. [PubMed: 22975404]

Hodges RR, Horikawa Y, Rios JD, Shatos MA, Dartt DA. Effect of protein kinase C and Ca(2+) on p42/p44 MAPK, Pyk2, and Src activation in rat conjunctival goblet cells. Exp Eye Res. 2007; 85:836-844. [PubMed: 17919561]

Hori Y, Spurr-Michaud S, Russo CL, Argueso P, Gipson IK. Differential regulation of membraneassociated mucins in the human ocular surface epithelium. Invest Ophthalmol Vis Sci. 2004; 45:114-122. [PubMed: 14691162]

Hori Y, Spurr-Michaud SJ, Russo CL, Argueso P, Gipson IK. Effect of retinoic acid on gene expression in human conjunctival epithelium: secretory phospholipase A2 mediates retinoic acid induction of MUC16. Invest Ophthalmol Vis Sci. 2005; 46:4050-4061. [PubMed: 16249480]

Horikawa Y, Shatos MA, Hodges RR, Zoukhri D, Rios JD, Chang EL, Bernardino CR, Rubin PA, Dartt DA. Activation of mitogen-activated protein kinase by cholinergic agonists and EGF in human compared with rat cultured conjunctival goblet cells. Invest Ophthalmol Vis Sci. 2003; 44:2535-2544. [PubMed: 12766054]

Imbert Y, Darling DS, Jumblatt MM, Foulks GN, Couzin EG, Steele PS, Young WW Jr. MUC1 splice variants in human ocular surface tissues: possible differences between dry eye patients and normal controls. Exp Eye Res. 2006; 83:493-501. [PubMed: 16631167]

Inatomi T, Tisdale AS, Zhan Q, Spurr-Michaud S, Gipson IK. Cloning of rat Muc5AC mucin gene: comparison of its structure and tissue distribution to that of human and mouse homologues. Biochem Biophys Res Commun. 1997; 236:789-797. [PubMed: 9245735]

Exp Eye Res. Author manuscript; available in PMC 2014 December 01. 
Jain P, Li R, Lama T, Saragovi HU, Cumberlidge G, Meerovitch K. An NGF mimetic, MIM-D3, stimulates conjunctival cell glycoconjugate secretion and demonstrates therapeutic efficacy in a rat model of dry eye. Exp Eye Res. 2011; 93:503-512. [PubMed: 21726552]

Johansson ME, Ambort D, Pelaseyed T, Schutte A, Gustafsson JK, Ermund A, Subramani DB, Holmen-Larsson JM, Thomsson KA, Bergstrom JH, van der Post S, Rodriguez-Pineiro AM, Sjovall H, Backstrom M, Hansson GC. Composition and functional role of the mucus layers in the intestine. Cellular and molecular life sciences : CMLS. 2011; 68:3635-3641. [PubMed: 21947475]

Jonckheere N, Van Seuningen I. The membrane-bound mucins: From cell signalling to transcriptional regulation and expression in epithelial cancers. Biochimie. 2010; 92:1-11. [PubMed: 19818375]

Jumblatt JE, Jumblatt MM. Regulation of ocular mucin secretion by P2Y2 nucleotide receptors in rabbit and human conjunctiva. Exp Eye Res. 1998; 67:341-346. [PubMed: 9778415]

Jumblatt MM, McKenzie RW, Steele PS, Emberts CG, Jumblatt JE. MUC7 expression in the human lacrimal gland and conjunctiva. Cornea. 2003; 22:41-45. [PubMed: 12502947]

Kanno H, Horikawa Y, Hodges RR, Zoukhri D, Shatos MA, Rios JD, Dartt DA. Cholinergic agonists transactivate EGFR and stimulate MAPK to induce goblet cell secretion. Am J Physiol Cell Physiol. 2003; 284:C988-998. [PubMed: 12620895]

Kardon R, Price RE, Julian J, Lagow E, Tseng SC, Gendler SJ, Carson DD. Bacterial conjunctivitis in Muc1 null mice. Invest Ophthalmol Vis Sci. 1999; 40:1328-1335. [PubMed: 10359313]

Kato K, Lillehoj EP, Park YS, Umehara T, Hoffman NE, Madesh M, Kim KC. Membrane-tethered MUC1 mucin is phosphorylated by epidermal growth factor receptor in airway epithelial cells and associates with TLR5 to inhibit recruitment of MyD88. Journal of immunology. 2012; 188:20142022.

Kenchegowda D, Swamynathan S, Gupta D, Wan H, Whitsett J, Swamynathan SK. Conditional disruption of mouse Klf5 results in defective eyelids with malformed meibomian glands, abnormal cornea and loss of conjunctival goblet cells. Dev Biol. 2011; 356:5-18. [PubMed: 21600198]

Kesimer M, Makhov AM, Griffith JD, Verdugo P, Sheehan JK. Unpacking a gel-forming mucin: a view of MUC5B organization after granular release. American journal of physiology. Lung cellular and molecular physiology. 2010; 298:L15-22. [PubMed: 19783639]

Kessing SV. Mucous gland system of the conjunctiva. A quantitative normal anatomical study. Acta Ophthalmol (Copenh), Suppl. 1968; 95:91+.

Kessler TL, Mercer HJ, Zieske JD, McCarthy DM, Dartt DA. Stimulation of goblet cell mucous secretion by activation of nerves in rat conjunctiva. Curr Eye Res. 1995; 14:985-992. [PubMed: 8585937]

Kim YS, Ho SB. Intestinal goblet cells and mucins in health and disease: recent insights and progress. Curr Gastroenterol Rep. 2010; 12:319-330. [PubMed: 20703838]

Kinjo M, Okegawa T, Horie S, Nutahara K, Higashihara E. Detection of circulating MUC7-positive cells by reverse transcription-polymerase chain reaction in bladder cancer patients. Int J Urol. 2004; 11:38-43. [PubMed: 14678183]

Kirkbride HJ, Bolscher JG, Nazmi K, Vinall LE, Nash MW, Moss FM, Mitchell DM, Swallow DM. Genetic polymorphism of MUC7: allele frequencies and association with asthma. Eur J Hum Genet. 2001; 9:347-354. [PubMed: 11378823]

Knop E, Knop N, Millar T, Obata H, Sullivan DA. The international workshop on meibomian gland dysfunction: report of the subcommittee on anatomy, physiology, and pathophysiology of the meibomian gland. Invest Ophthalmol Vis Sci. 2011; 52:1938-1978. [PubMed: 21450915]

Knop N, Knop E. Regulation of the inflammatory component in chronic dry eye disease by the eyeassociated lymphoid tissue (EALT). Developments in ophthalmology. 2010; 45:23-39. [PubMed: 20502024]

Komatsu M, Carraway CA, Fregien NL, Carraway KL. Reversible disruption of cell- matrix and cellcell interactions by overexpression of sialomucin complex. The Journal of biological chemistry. 1997; 272:33245-33254. [PubMed: 9407114]

Kunert KS, Keane-Myers AM, Spurr-Michaud S, Tisdale AS, Gipson IK. Alteration in goblet cell numbers and mucin gene expression in a mouse model of allergic conjunctivitis. Invest Ophthalmol Vis Sci. 2001; 42:2483-2489. [PubMed: 11581187]

Exp Eye Res. Author manuscript; available in PMC 2014 December 01. 
Lambiase A, Micera A, Pellegrini G, Merlo D, Rama P, De Luca M, Bonini S. In vitro evidence of nerve growth factor effects on human conjunctival epithelial cell differentiation and mucin gene expression. Invest Ophthalmol Vis Sci. 2009; 50:4622-4630. [PubMed: 19407015]

Lange C, Fernandez J, Shim D, Spurr-Michaud S, Tisdale A, Gipson IK. Mucin gene expression is not regulated by estrogen and/or progesterone in the ocular surface epithelia of mice. Exp Eye Res. 2003; 77:59-68. [PubMed: 12823988]

Lemp, MA. Basic principles and classifications of dry eye disorders. In: Lemp, MA.; Marquandt, R., editors. The dry eye: a comprehensive guide. Springer; New York: 1992. p. 101-131.

Li D, Hodges RR, Jiao J, Carozza RB, Shatos MA, Chiang N, Serhan CN, Dartt DA. Resolvin D1 and aspirin-triggered resolvin D1 regulate histamine-stimulated conjunctival goblet cell secretion. Mucosal Immunol. 2013a

Li D, Jiao J, Shatos MA, Hodges RR, Dartt DA. Effect of VIP on Intracellular [Ca2+], Extracellular Regulated Kinase 1/2, and Secretion in Cultured Rat Conjunctival Goblet Cells. Invest Ophthalmol Vis Sci. 2013b; 54:2872-2884. [PubMed: 23518767]

Li S, Bobek LA. Functional analysis of human MUC7 mucin gene 5'-flanking region in lung epithelial cells. Am J Respir Cell Mol Biol. 2006; 35:593-601. [PubMed: 16778149]

Li YY, Chang JW, Hsieh LL, Yeh KY. Neutralization of interleukin (IL)-10 released by monocytes/ macrophages enhances the up-regulatory effect of monocyte/macrophage-derived IL-6 on expressions of IL-6 and MUC1, and migration in HT-29 colon cancer cells. Cell Immunol. 2010; 265:164-171. [PubMed: 20851386]

Ma M, Zhang Z, Niu W, Zheng W, Kelimu J, Ke B. Fibroblast growth factor 10 upregulates the expression of mucins in rat conjunctival epithelial cells. Mol Vis. 2011; 17:2789-2797. [PubMed: 22065934]

Mantelli F, Moretti C, Micera A, Bonini S. Conjunctival mucin deficiency in complete androgen insensitivity syndrome (CAIS). Graefes Arch Clin Exp Ophthalmol. 2007; 245:899-902. [PubMed: 17120009]

Mantelli F, Schaffer L, Dana R, Head SR, Argueso P. Glycogene expression in conjunctiva of patients with dry eye: downregulation of Notch signaling. Invest Ophthalmol Vis Sci. 2009; 50:26662672. [PubMed: 19011014]

McGuckin MA, Quin RJ, Ward BG. Progesterone stimulates production and secretion of MUC1 epithelial mucin in steroid-responsive breast cancer cell lines. Int J Oncol. 1998; 12:939-945. [PubMed: 9499459]

McKenzie RW, Jumblatt JE, Jumblatt MM. Quantification of MUC2 and MUC5AC transcripts in human conjunctiva. Invest Ophthalmol Vis Sci. 2000; 41:703-708. [PubMed: 10711684]

Merayo-Lloves J, Calonge M, Foster CS. Experimental model of allergic conjunctivitis to ragweed in guinea pig. Curr Eye Res. 1995; 14:487-494. [PubMed: 7671631]

Mitchell S, Abel P, Madaan S, Jeffs J, Chaudhary K, Stamp G, Lalani el N. Androgen-dependent regulation of human MUC1 mucin expression. Neoplasia. 2002; 4:9-18. [PubMed: 11922395]

Moore JE, Vasey GT, Dartt DA, McGilligan VE, Atkinson SD, Grills C, Lamey PJ, Leccisotti A, Frazer DG, Moore TC. Effect of tear hyperosmolarity and signs of clinical ocular surface pathology upon conjunctival goblet cell function in the human ocular surface. Invest Ophthalmol Vis Sci. 2011; 52:6174-6180. [PubMed: 21519030]

Murakami T, Fujihara T, Nakamura M, Nakata K. P2Y(2) receptor elicits PAS-positive glycoprotein secretion from rabbit conjunctival goblet cells in vivo. J Ocul Pharmacol Ther. 2003; 19:345-352. [PubMed: 12964958]

Neutra MR, O'Malley LJ, Specian RD. Regulation of intestinal goblet cell secretion. II. A survey of potential secretagogues. Am J Physiol. 1982; 242:G380-387. [PubMed: 7065260]

Neutra MR, Phillips TL, Phillips TE. Regulation of intestinal goblet cells in situ, in mucosal explants and in the isolated epithelium. Ciba Found Symp. 1984; 109:20-39. [PubMed: 6394244]

Niv Y, Boltin D. Secreted and membrane-bound mucins and idiopathic peptic ulcer disease. Digestion. 2012; 86:258-263. [PubMed: 23075498]

Paulsen F. Functional anatomy and immunological interactions of ocular surface and adnexa. Developments in ophthalmology. 2008; 41:21-35. [PubMed: 18453759]

Exp Eye Res. Author manuscript; available in PMC 2014 December 01. 
Paulsen F, Jager K, Worlitzsch D, Brauer L, Schulze U, Schafer G, Sel S. Regulation of MUC16 by inflammatory mediators in ocular surface epithelial cell lines. Ann Anat. 2008; 190:59-70. [PubMed: 18342144]

Paulsen F, Langer G, Hoffmann W, Berry M. Human lacrimal gland mucins. Cell Tissue Res. 2004; 316:167-177. [PubMed: 15052468]

Pellegrini G, Golisano O, Paterna P, Lambiase A, Bonini S, Rama P, De Luca M. Location and clonal analysis of stem cells and their differentiated progeny in the human ocular surface. J Cell Biol. 1999; 145:769-782. [PubMed: 10330405]

Perez-Vilar J, Mabolo R, McVaugh CT, Bertozzi CR, Boucher RC. Mucin granule intraluminal organization in living mucous/goblet cells. Roles of protein post-translational modifications and secretion. The Journal of biological chemistry. 2006; 281:4844-4855. [PubMed: 16377632]

Perez BH, Gipson IK. Focus on Molecules: human mucin MUC16. Exp Eye Res. 2008; 87:400-401. [PubMed: 18289532]

Pflugfelder SC, Jones D, Ji Z, Afonso A, Monroy D. Altered cytokine balance in the tear fluid and conjunctiva of patients with Sjogren's syndrome keratoconjunctivitis sicca. Curr Eye Res. 1999; 19:201-211. [PubMed: 10487957]

Pflugfelder SC, Liu Z, Monroy D, Li DQ, Carvajal ME, Price-Schiavi SA, Idris N, Solomon A, Perez A, Carraway KL. Detection of sialomucin complex (MUC4) in human ocular surface epithelium and tear fluid. Invest Ophthalmol Vis Sci. 2000; 41:1316-1326. [PubMed: 10798646]

Raina D, Ahmad R, Chen D, Kumar S, Kharbanda S, Kufe D. MUC1 oncoprotein suppresses activation of the ARF-MDM2-p53 pathway. Cancer Biol Ther. 2008; 7:1959-1967. [PubMed: 18981727]

Retz M, Lehmann J, Szysnik C, Zwank S, Venzke T, Roder C, Kalthoff H, Basbaum C, Stockle M. Detection of occult tumor cells in lymph nodes from bladder cancer patients by MUC7 nested RT-PCR. Eur Urol. 2004; 45:314-319. [PubMed: 15036676]

Ricciuto J, Heimer SR, Gilmore MS, Argueso P. Cell surface O-glycans limit Staphylococcus aureus adherence to corneal epithelial cells. Infect Immun. 2008; 76:5215-5220. [PubMed: 18794288]

Rios JD, Forde K, Diebold Y, Lightman J, Zieske JD, Dartt DA. Development of conjunctival goblet cells and their neuroreceptor subtype expression. Invest Ophthalmol Vis Sci. 2000; 41:21272137. [PubMed: 10892854]

Rios JD, Ghinelli E, Gu J, Hodges RR, Dartt DA. Role of neurotrophins and neurotrophin receptors in rat conjunctival goblet cell secretion and proliferation. Invest Ophthalmol Vis Sci. 2007; 48:1543-1551. [PubMed: 17389483]

Rios JD, Zoukhri D, Rawe IM, Hodges RR, Zieske JD, Dartt DA. Immunolocalization of muscarinic and VIP receptor subtypes and their role in stimulating goblet cell secretion. Invest Ophthalmol Vis Sci. 1999; 40:1102-1111. [PubMed: 10235543]

Roat MI, Ohji M, Hunt LE, Thoft RA. Conjunctival epithelial cell hypermitosis and goblet cell hyperplasia in atopic keratoconjunctivitis. Am J Ophthalmol. 1993; 116:456-463. [PubMed: 8213976]

Rose MC, Voynow JA. Respiratory tract mucin genes and mucin glycoproteins in health and disease. Physiol Rev. 2006; 86:245-278. [PubMed: 16371599]

Rousseau K, Vinall LE, Butterworth SL, Hardy RJ, Holloway J, Wadsworth ME, Swallow DM. MUC7 haplotype analysis: results from a longitudinal birth cohort support protective effect of the MUC7*5 allele on respiratory function. Annals of human genetics. 2006; 70:417-427. [PubMed: 16759176]

Seo KY, Chung SH, Lee JH, Park MY, Kim EK. Regulation of membrane-associated mucins in the human corneal epithelial cells by dexamethasone. Cornea. 2007; 26:709-714. [PubMed: 17592322]

Serhan CN, Petasis NA. Resolvins and protectins in inflammation resolution. Chem Rev. 2011; 111:5922-5943. [PubMed: 21766791]

Shatos MA, Gu J, Hodges RR, Lashkari K, Dartt DA. ERK/p44p42 mitogen-activated protein kinase mediates EGF-stimulated proliferation of conjunctival goblet cells in culture. Investigative ophthalmology \& visual science. 2008; 49:3351-3359. [PubMed: 18421078]

Exp Eye Res. Author manuscript; available in PMC 2014 December 01. 
Shatos MA, Hodges RR, Bair JA, Lashkari K, Dartt DA. Stimulatory role of PKCalpha in extracellular regulated kinase $1 / 2$ pathway in conjunctival goblet cell proliferation. Investigative ophthalmology \& visual science. 2009a; 50:1619-1625. [PubMed: 19074803]

Shatos MA, Hodges RR, Oshi Y, Bair JA, Zoukhri D, Kublin C, Lashkari K, Dartt DA. Role of cPKCalpha and nPKCepsilon in EGF-stimulated goblet cell proliferation. Investigative ophthalmology \& visual science. 2009b; 50:614-620. [PubMed: 18824739]

Shatos MA, Rios JD, Horikawa Y, Hodges RR, Chang EL, Bernardino CR, Rubin PA, Dartt DA. Isolation and characterization of cultured human conjunctival goblet cells. Invest Ophthalmol Vis Sci. 2003; 44:2477-2486. [PubMed: 12766046]

Shatos MA, Rios JD, Tepavcevic V, Kano H, Hodges R, Dartt DA. Isolation, characterization, and propagation of rat conjunctival goblet cells in vitro. Invest Ophthalmol Vis Sci. 2001; 42:14551464. [PubMed: 11381047]

Sheehan JK, Kirkham S, Howard M, Woodman P, Kutay S, Brazeau C, Buckley J, Thornton DJ. Identification of molecular intermediates in the assembly pathway of the MUC5AC mucin. The Journal of biological chemistry. 2004; 279:15698-15705. [PubMed: 14749330]

Sheng YH, Hasnain SZ, Florin TH, McGuckin MA. Mucins in inflammatory bowel diseases and colorectal cancer. J Gastroenterol Hepatol. 2012; 27:28-38. [PubMed: 21913981]

Silva DG, Stevens RH, Macedo JM, Hirata R, Pinto AC, Alves LM, Veerman EC, Tinoco EM. Higher levels of salivary MUC5B and MUC7 in individuals with gastric diseases who harbor Helicobacter pylori. Arch Oral Biol. 2009; 54:86-90. [PubMed: 18817906]

Silverman HS, Parry S, Sutton-Smith M, Burdick MD, McDermott K, Reid CJ, Batra SK, Morris HR, Hollingsworth MA, Dell A, Harris A. In vivo glycosylation of mucin tandem repeats. Glycobiology. 2001; 11:459-471. [PubMed: 11445551]

Singh PK, Hollingsworth MA. Cell surface-associated mucins in signal transduction. Trends in cell biology. 2006; 16:467-476. [PubMed: 16904320]

Situ H, Bobek LA. In vitro assessment of antifungal therapeutic potential of salivary histatin-5, two variants of histatin-5, and salivary mucin (MUC7) domain 1. Antimicrob Agents Chemother. 2000; 44:1485-1493. [PubMed: 10817697]

Solomon A, Dursun D, Liu Z, Xie Y, Macri A, Pflugfelder SC. Pro- and anti-inflammatory forms of interleukin-1 in the tear fluid and conjunctiva of patients with dry-eye disease. Invest Ophthalmol Vis Sci. 2001; 42:2283-2292. [PubMed: 11527941]

Spurr-Michaud S, Argueso P, Gipson I. Assay of mucins in human tear fluid. Experimental eye research. 2007; 84:939-950. [PubMed: 17399701]

Tan L, Psaltis A, Baker LM, McGuckin M, Rousseau K, Wormald PJ. Aberrant mucin glycoprotein patterns of chronic rhinosinusitis patients with bacterial biofilms. Am J Rhinol Allergy. 2010; 24:319-324. [PubMed: 21244730]

Tei M, Moccia R, Gipson IK. Developmental expression of mucin genes ASGP (rMuc4) and rMuc5ac by the rat ocular surface epithelium. Invest Ophthalmol Vis Sci. 1999; 40:1944-1951. [PubMed: 10440247]

Thai P, Loukoianov A, Wachi S, Wu R. Regulation of airway mucin gene expression. Annu Rev Physiol. 2008; 70:405-429. [PubMed: 17961085]

Theodoropoulos G, Carraway KL. Molecular signaling in the regulation of mucins. J Cell Biochem. 2007; 102:1103-1116. [PubMed: 17957706]

Tishler M, Yaron I, Geyer O, Shirazi I, Naftaliev E, Yaron M. Elevated tear interleukin-6 levels in patients with Sjogren syndrome. Ophthalmology. 1998; 105:2327-2329. [PubMed: 9855167]

Toda I, Shimazaki J, Tsubota K. Dry eye with only decreased tear break-up time is sometimes associated with allergic conjunctivitis. Ophthalmology. 1995; 102:302-309. [PubMed: 7862418]

Treon SP, Mollick JA, Urashima M, Teoh G, Chauhan D, Ogata A, Raje N, Hilgers JH, Nadler L, Belch AR, Pilarski LM, Anderson KC. Muc-1 core protein is expressed on multiple myeloma cells and is induced by dexamethasone. Blood. 1999; 93:1287-1298. [PubMed: 9949172]

Wang IJ, Yu CJ, Hu FR. Alteration of ocular surface mucins in MUC5AC-DTA transgenic mice. Mol Vis. 2009; 15:108-119. [PubMed: 19158956]

Exp Eye Res. Author manuscript; available in PMC 2014 December 01. 
Watson AM, Ngor WM, Gordish-Dressman H, Freishtat RJ, Rose MC. MUC7 polymorphisms are associated with a decreased risk of a diagnosis of asthma in an African American population. $\mathrm{J}$ Investig Med. 2009; 57:882-886.

Wei ZG, Cotsarelis G, Sun TT, Lavker RM. Label-retaining cells are preferentially located in fornical epithelium: implications on conjunctival epithelial homeostasis. Invest Ophthalmol Vis Sci. 1995; 36:236-246. [PubMed: 7822151]

Woo HJ, Bae CH, Song SY, Lee HM, Kim YD. Expression of membrane-bound mucins in human nasal mucosa: different patterns for MUC4 and MUC16. Arch Otolaryngol Head Neck Surg. 2010; 136:603-609. [PubMed: 20566912]

Xiong L, Woodward AM, Argueso P. Notch signaling modulates MUC16 biosynthesis in an in vitro model of human corneal and conjunctival epithelial cell differentiation. Invest Ophthalmol Vis Sci. 2011; 52:5641-5646. [PubMed: 21508102]

Yoon JH, Kim KS, Kim SS, Lee JG, Park IY. Secretory differentiation of serially passaged normal human nasal epithelial cells by retinoic acid: expression of mucin and lysozyme. Ann Otol Rhinol Laryngol. 2000; 109:594-601. [PubMed: 10855573]

Yu DF, Chen Y, Han JM, Zhang H, Chen XP, Zou WJ, Liang LY, Xu CC, Liu ZG. MUC19 expression in human ocular surface and lacrimal gland and its alteration in Sjogren syndrome patients. Exp Eye Res. 2008; 86:403-411. [PubMed: 18184611]

Zhang Y, Lam O, Nguyen MT, Ng G, Pear WS, Ai W, Wang IJ, Kao WW, Liu CY. Mastermind-like transcriptional co-activator-mediated Notch signaling is indispensable for maintaining conjunctival epithelial identity. Development. 2013; 140:594-605. [PubMed: 23293291]

Exp Eye Res. Author manuscript; available in PMC 2014 December 01. 
1. The cornea, conjunctiva and tear film interact with the external environment.

2. The ocular surface is protected from environmental challenges by the tear film.

3. The innermost layer of the tear film is the mucous layer.

4. This review focuses on the mucins produced by the cornea and conjunctiva. 


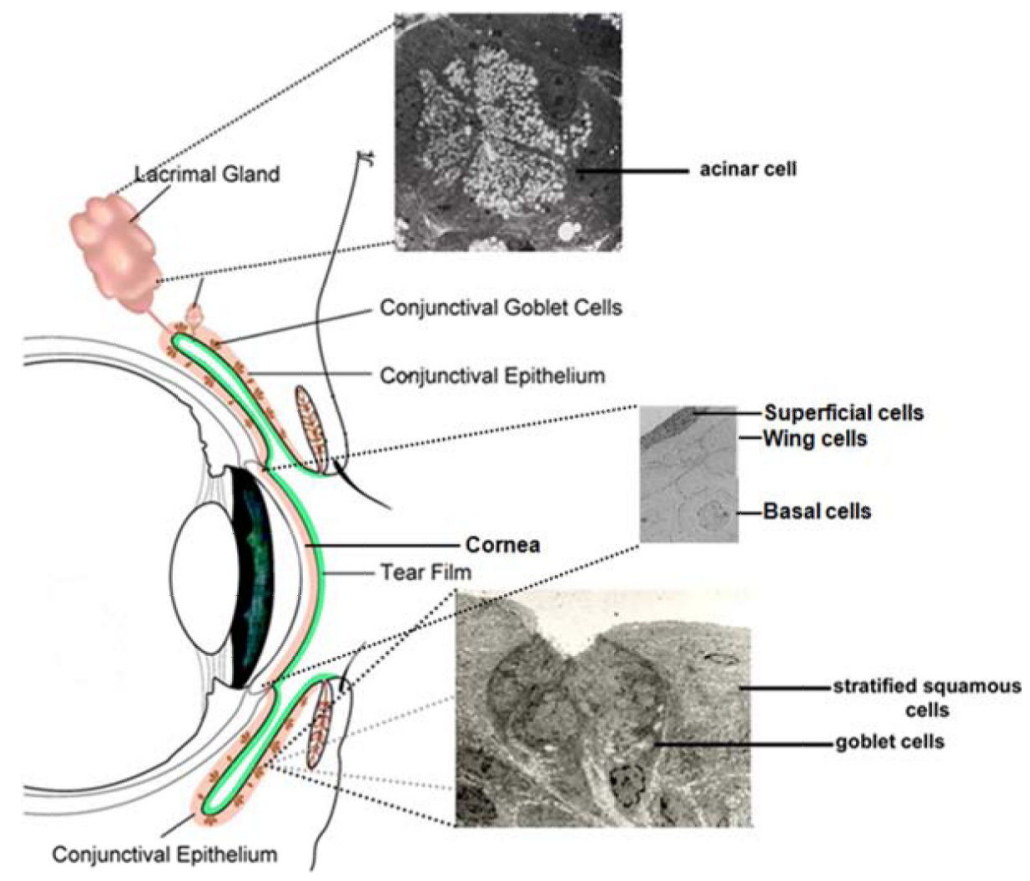

Figure 1.

Mucin Producing Tissues of the Ocular Surface. Acinar cells of the lacrimal gland, epithelial cells of the cornea and conjunctiva, and goblet cells of the conjunctiva synthesize and secrete mucins onto the ocular surface. Photographs are electron micrographs of indicated tissue. Micrograph of cornea is reproduced from Gipson and Joyce. Anatomy and Cell Biology of the Cornea, Superficial Limbus; and Conjunctiva in Principles and Practice of Ophthalmology. 2000 Albert and Jakobiec, ed. WB Saunders Company, Philadelphia.

Exp Eye Res. Author manuscript; available in PMC 2014 December 01. 
A

\section{Cornea}

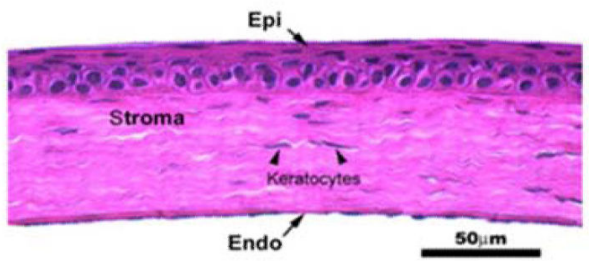

B

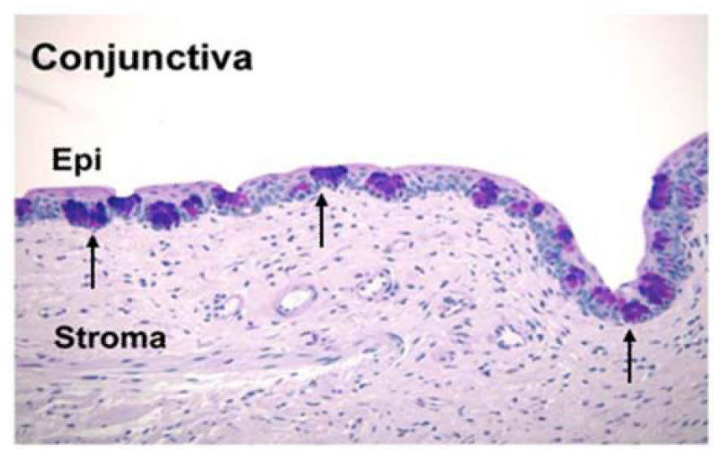

Figure 2.

Structure of cornea and conjunctiva. Hematoxylin and eosin staining of human cornea (A). Arrow at the top of tissue indicates epithelium while arrow at bottom of tissue indicates endothelium. Arrowheads indicate keratocytes present in the stroma. Reprinted from Leal and Pearlman, The role of cytokines and pathogen recognition molecules in fungal keratitis - Insights from human disease and animal models. Cytokines 2012 58:107-111. Alcian blue/ periodic acid Schiff reagent staining of rat conjunctiva (B). Arrows indicate clusters of several goblet cells. Reprinted from Shatos et al. Isolation, characterization, and propagation of rat conjunctival goblet cells in vitro. Invest Ophthalmol Vis Sci 2001, 42:1455-1464. Epi: epithelium; Endo: endothelium.

Exp Eye Res. Author manuscript; available in PMC 2014 December 01. 


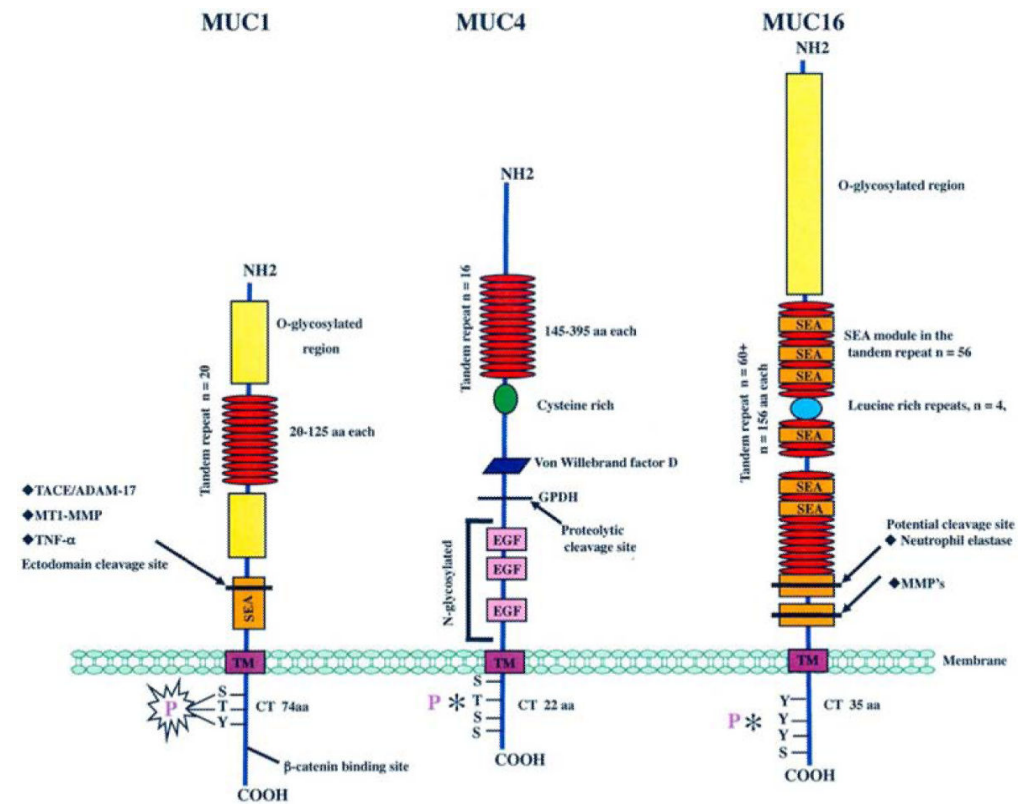

Figure 3.

Schematic diagram of structures of membrane spanning mucins. CT: cytoplasmic tails; SEA: Sea urchin sperm protein Enterokinase and Agrin module; GPDH: glycerol-3phosphate dehydrogenase; $\mathrm{S}$ : serine residues; $\mathrm{T}$ : threonine residues; $\mathrm{Y}$ : tyrosine residues. Reprinted from Govindarjan and Gipson. Membrane-tethered mucins have multiple functions on the ocular surface. Exp Eye Res. 2010, 90:655-663. 


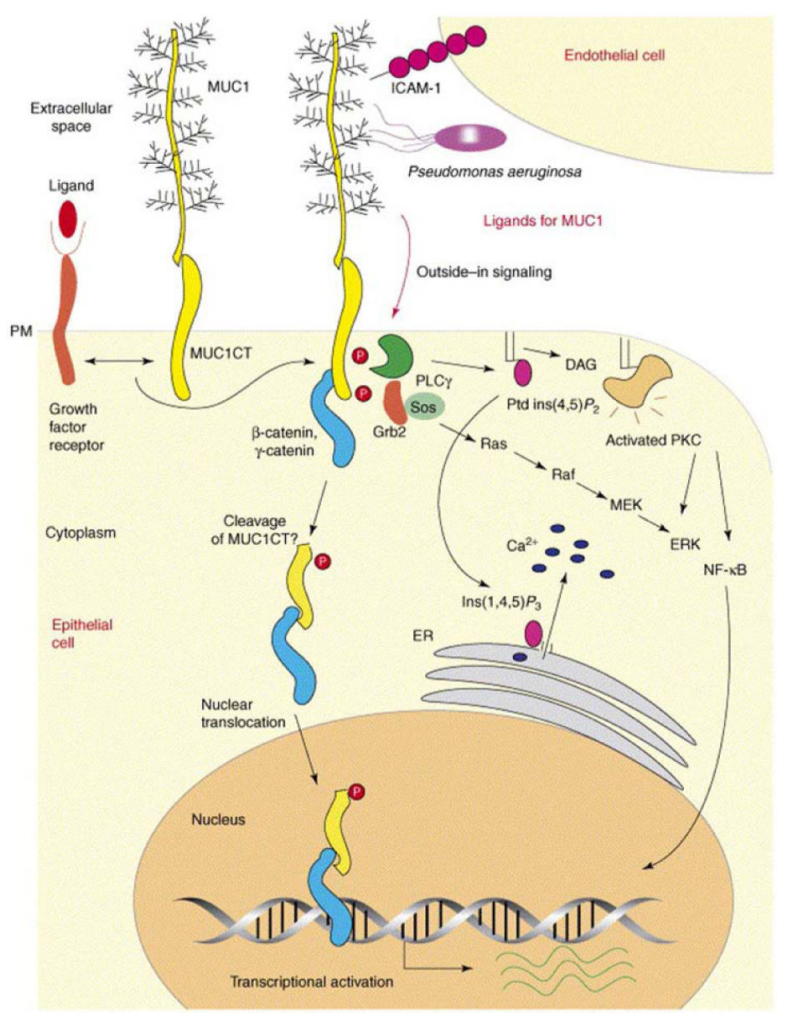

Figure 4.

Outsid-in Signaling by MUC1. MUC1 signaling can be mediated by phosphorylation of hte MUC1CT by ligand binding and activation of a growth factor receptor, interactions with ICAM-1 or bacteria binding to activate several signaling pathways. The MUC1CT can be cleaved and translocate to the nucleus and potentially regulate genes. ICAM-1, intracellular adhesion molecule 1; PLC $\gamma$, phospholipase $\mathrm{C} \gamma$; DAG, diacylglycerol; PKC, protein kinase C; PM, plasma membrane; ER, endoplasmic reticulum; Grb2: growth factor receptor-bound protein; Sos: a guanine nucleotide exchange factor ; Ras: small GTPase; Raf: mitogenactivated protein kinase kinase kinase; MEK: mitogen-activated protein kinase kinase; ERK, extracellular regulated kinase; NF- $\kappa \mathrm{B}$ - nuclear factor $\kappa \mathrm{B}$; From Singh and Hollingsworth. Cell surface-associated mucins in signal transduction. Trends in Cell Biol 2006, 16:467-476.

Exp Eye Res. Author manuscript; available in PMC 2014 December 01. 
MUC7
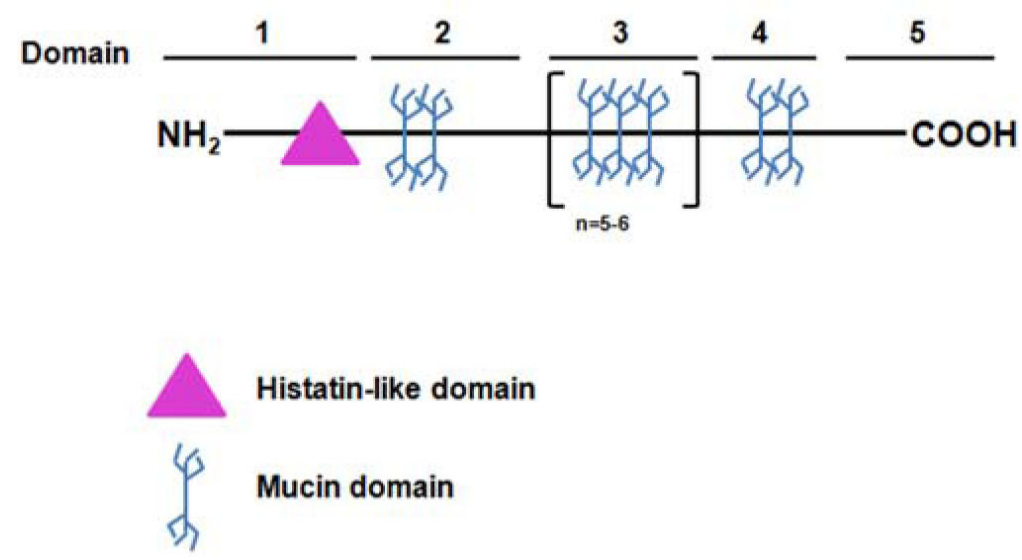

Figure 5.

Schematic diagram of the structure of the protein core of the small secretory mucin MUC7. Modified from Gipson and Argueso. Role of Mucins in the Function of the Corneal and Conjunctival Epithelia. Int Rev Cytol. 2003, 231:1-49. 


\section{MUC5AC}
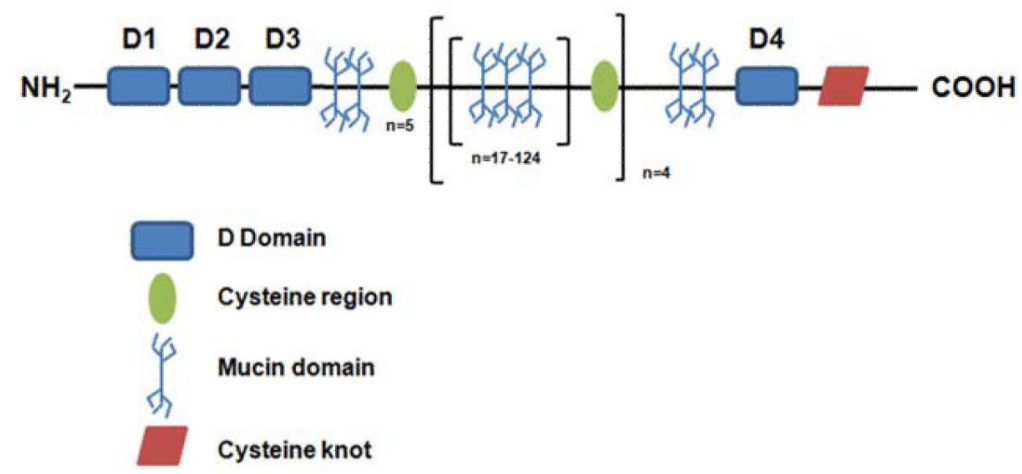

Figure 6.

Schematic diagram of the structure of the protein core of the gel-forming mucin MUC5AC. Modified from Gipson and Argueso. Role of Mucins in the Function of the Corneal and Conjunctival Epithelia. Int Rev Cytol. 2003, 231:1-49. 


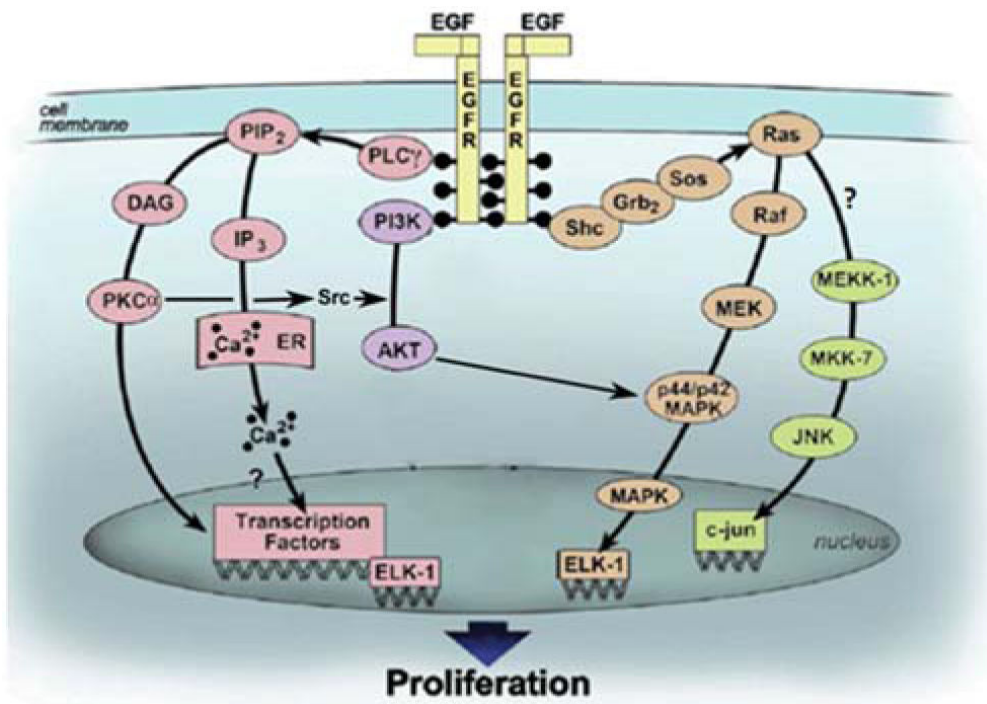

Figure 7.

Schematic diagram of EGF signaling pathway to stimulate proliferation of conjunctival goblet cells. $\mathrm{PIP}_{2}$ : phosphatidylinositol 4,5-bisphosphate; DAG: diacylglycerol; PKCa: protein kinase $\mathrm{Ca} ; \mathrm{IP}_{3}$ : inositol trisphosphate; ER: endoplasmic reticulum; PLC $\gamma$ : phospholipase $\mathrm{C} \gamma$; PI3K: phosphoinositide 3-kinase; AKT: protein kinase B; EGF: epidermal growth factor; EGFR: epidermal growth factor receptor; Shc: adaptor protein; Grb2: growth factor receptor-bound protein; Sos: a guanine nucleotide exchange factor ; Ras: small GTPase; Raf: mitogen-activated protein kinase kinase kinase; MEK: mitogenactivated protein kinase kinase; MAPK: mitogen-activated protein kinase (also known as extracellular regulated kinase (ERK) 1/2); MEKK-1: mitogen-activated protein kinase kinase kinase 1; MKK7: mitogen-activated protein kinase kinase 7; JNK: c-Jun N-terminal kinase; c-jun: transcription factor; ELK-1: transcription activator. 

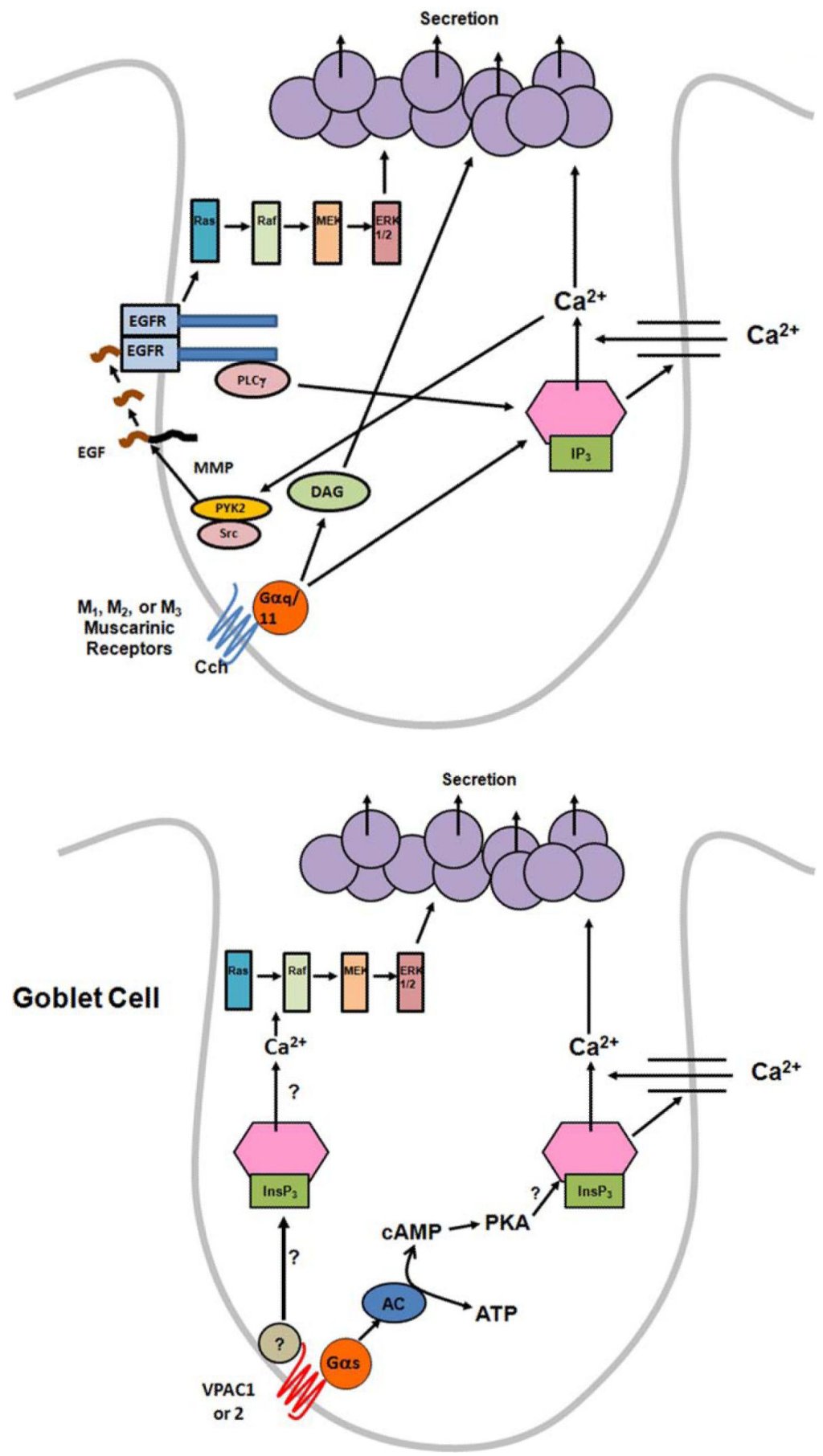

Figure 8.

Schematic diagram of signaling pathways used to stimulate mucin secretion in conjunctival goblet cells. Signaling pathway used by cholinergic agonists (A) or vasoactive intestinal peptide (VIP, B) to stimulate mucin secretion. EGF: epidermal growth factor; EGFR: epidermal growth factor receptor; Ras: small GTPase; Raf: mitogen-activated protein kinase kinase kinase; MEK: mitogen-activated protein kinase kinase; ERK 1/2: extracellular regulated kinase (ERK) 1/2 (also known as mitogen-activated protein kinase (MAPK)); 
PLC $\gamma$ : phospholipase $\mathrm{C} \gamma$; MMP: matrix metalloproteinase; Pyk2: a nonreceptor tyrosine kinase; Src: a nonreceptor tyrosine kinase; DAG: diacylglycerol; $\mathrm{IP}_{3}$ : inositol trisphosphate; $\mathrm{M}_{1}, \mathrm{M}_{2}, \mathrm{M}_{3}$ : muscarinic receptors of the $\mathrm{M}_{1}, \mathrm{M}_{2}$, and $\mathrm{M}_{3}$ subtypes; $\mathrm{Cch}$ : carbachol; a subunit of $\mathrm{G}_{\mathrm{q} / 11} \mathrm{G}$ protein; Gas: a subunit of $\mathrm{G}_{\mathrm{s}} \mathrm{G}$ protein; VPAC1 and 2: vasoactive intestinal peptide receptors 1 and 2; AC: adenylate cyclase; cAMP: cyclic adenosine monophosphate; PKA: protein kinase A. Reprinted from Li et al Effect of VIP on intracellular $\left[\mathrm{Ca}^{2+}\right]$, extracellular regulated kinase $1 / 2$, and secretion in cultured rat conjunctival goblet cells. Invest Ophthalmol Vis Sci 2013 23:2872-2884.

Exp Eye Res. Author manuscript; available in PMC 2014 December 01. 


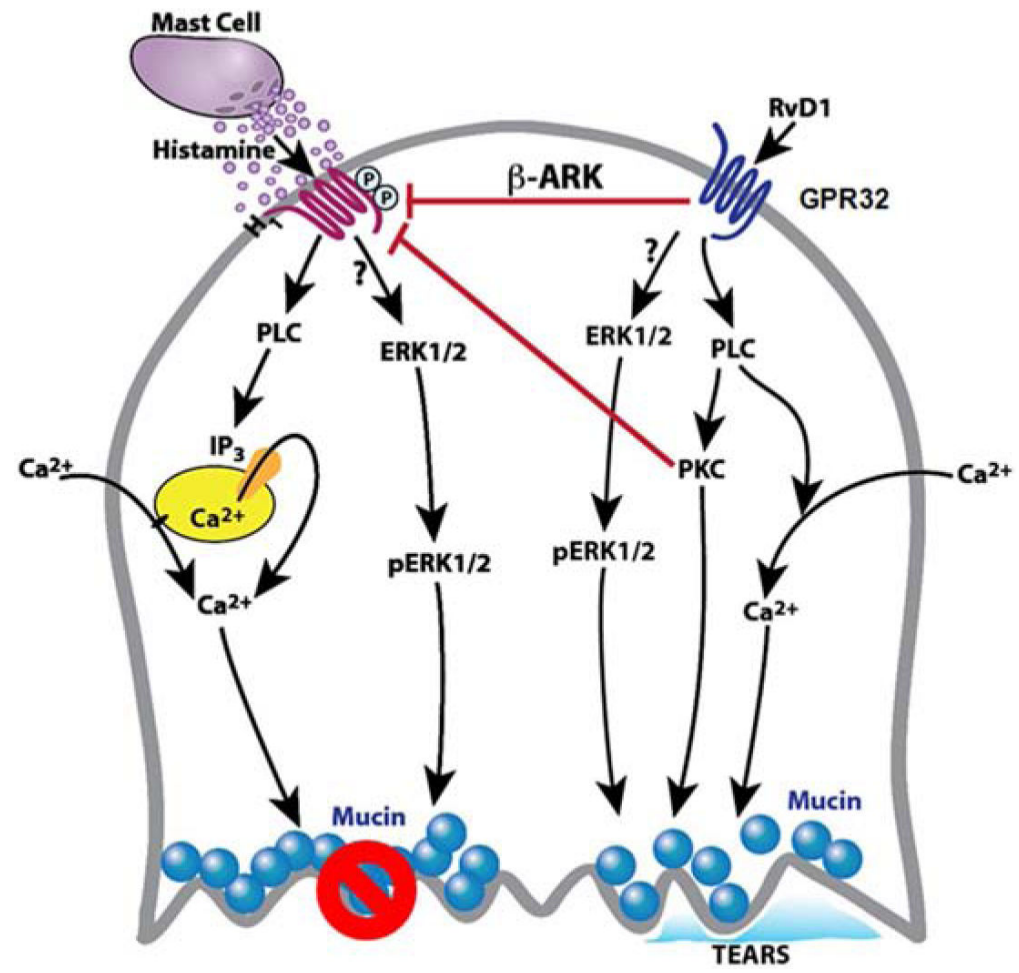

Figure 9.

Counter regulation of the $\mathrm{H} 1$ histamine receptor by resolvin D1 in conjunctival goblet cells to prevent histamine stimulation of secretion. $\mathrm{H}_{1}$ : histamine receptor subtype 1 ; PLC: phospholipase $\mathrm{C} ; \mathrm{IP}_{3}$ : inositol trisphosphate; ERK 1/2: extracellular regulated kinase (ERK) $1 / 2$ (also known as mitogen-activated protein kinase (MAPK)); pERK1/2; phosphorylated (active) ERK; $\beta$-ARK: $\beta$-adrenergic receptor kinase (also known as $G$ protein-coupled receptor kinase (GRK) 2); RvD1: resolvin D1; GPR32: G protein-coupled receptor 32); PKC: protein kinase C. 
Table 1

\begin{tabular}{|c|c|c|c|}
\hline Category & Conjunctiva & Airways & Gastrointestinal Tract \\
\hline Major Cell Types & Strat sq; GC & $\begin{array}{l}\text { Strat sq; mucus glands; Clara cells } \\
\text { differentiate to GC with infection }\end{array}$ & $\begin{array}{l}\text { Columnar crypt and villi; GC } \\
\text { migrate up crypt to tips of villi }\end{array}$ \\
\hline Membrane Associated Mucins & MUC $1,4,16$ & MUC $1,4,16$ & MUC $1,3,4,13,17$ \\
\hline Predominate Soluble Mucins & MUC 5AC & $\begin{array}{l}\text { MUC 5AC (GC); MUC5B (mucus } \\
\text { gland) }\end{array}$ & MUC 2 \\
\hline Major Regulation of Soluble Mucins & Secretion & Synthesis & Synthesis/secretion \\
\hline Mode of Stimulation of GC Secretion & Neural & $\begin{array}{l}\text { GC: inflammatory cytokines, } \\
\text { bacterial products, growth factors, } \\
\text { environmental chemicals \& } \\
\text { pollutants Mucous glands: neural }\end{array}$ & Neural/histamine \\
\hline Size of mucin layer & $1 \mu \mathrm{M}$ & $7-70 \mu \mathrm{M}$ & $480 \mu \mathrm{M}$ or greater \\
\hline Major Diseases & $\begin{array}{c}\text { Allergic } \\
\text { Conjunctivitis Dry } \\
\text { Eye }\end{array}$ & Asthma COPD CF & CF Infection IBD \\
\hline
\end{tabular}

Strat sq: stratified squamous cells; GC: goblet cell; COPD: chronic obstructive pulmonary disease; CF: cystic fibrosis; IBD: inflammatory bowel disease 